\title{
Distributed modeling of ablation (1996-2011) and climate sensitivity on the glaciers of Taylor Valley, Antarctica
}

\author{
MATTHEW J. HOFFMAN, ${ }^{1}$ ANDREW G. FOUNTAIN, ${ }^{2}$ GLEN E. LISTON ${ }^{3}$ \\ ${ }^{1}$ Fluid Dynamics Group, Los Alamos National Laboratory \\ ${ }^{2}$ Department of Geology, Portland State University \\ ${ }^{3}$ Cooperative Institute for Research in the Atmosphere, Colorado State University \\ Correspondence: Matthew J. Hoffman <mhoffman@lanl.gov>
}

\begin{abstract}
The McMurdo Dry Valleys of Antarctica host the coldest and driest ecosystem on Earth, which is acutely sensitive to the availability of water coming from glacial runoff. We modeled the spatial variability in ablation and assessed climate sensitivity of the glacier ablation zones using 16 years of meteorological and surface mass-balance observations collected in Taylor Valley. Sublimation was the primary form of mass loss over much of the ablation zones, except for near the termini where melt, primarily below the surface, dominated. Microclimates in $\sim 10 \mathrm{~m}$ scale topographic basins generated melt rates up to ten times higher than over smooth glacier surfaces. In contrast, the vertical terminal cliffs on the glaciers can have higher or lower melt rates than the horizontal surfaces due to differences in incoming solar radiation. The model systematically underpredicted ablation for the final $\mathbf{5}$ years studied, possibly due to an increase of windblown sediment. Surface mass-balance sensitivity to temperature was $\sim-0.02 \mathrm{~m}$ w.e. $\mathrm{K}^{-1}$, which is among the smallest magnitudes observed globally. We also identified a high sensitivity to ice albedo, with a decrease of 0.02 having similar effects as a $1 \mathrm{~K}$ increase in temperature, and a complex sensitivity to wind speed.
\end{abstract}

KEYWORDS: Antarctic glaciology, energy balance, glacier ablation phenomena, glacier mass balance, melt - surface

\section{INTRODUCTION}

The McMurdo Dry Valleys (MDV) of Victoria Land, Antarctica, are the largest ice-free region on the continent (Drewry and others, 1982; Levy, 2012), as well as a polar desert that is one of the coldest and driest on Earth (Fountain and others, 1999b). Snowfall is infrequent and most snow sublimates with relatively little melt to the soils and streams (Keys, 1980; Gooseff and others, 2006; Fountain and others, 2010; Hagedorn and others, 2010; Eveland and others, 2013). Consequently, glacier melt provides the primary source of water to ephemeral streams that flow for $\sim 10$ weeks each summer (Dana and Wharton, 1998; McKnight and others, 1999; Foreman and others, 2004). But the glacier surfaces are typically below the melt threshold during the summer and runoff is quite limited given the large expanse of ice present in the valleys (Fountain and others, 1998; Lewis and others, 1998; Bliss, 2005; Hoffman and others, 2008, 2014; MacDonell and others, 2012). Episodic ( decadal) warming events have been shown to have substantial impact on glacier ablation, hydrology, geomorphology and ecology of the MDV (Foreman and others, 2004; Doran and others, 2008; Nielsen and others, 2012; Levy and others, 2013; Fountain and others, 2014). The climate sensitivity of these glaciers, and polar glaciers in general (Oerlemans and Fortuin, 1992; Oerlemans and others, 1998; Cuffey and Paterson, 2010), has received little study.

Previous studies of glacier melt in the MDV have included both physically complete but spatially and/or temporally limited surface energy-balance models (Lewis and others,
1998, 1999; Bliss, 2005; Johnston and others, 2005; Hoffman and others, 2008, 2014; MacDonell and others, 2012) and spatio-temporally extensive but physically limited statistical models (Dana and others, 2002; Jaros, 2003; Ebnet and others, 2005; Jaros and others, 2014). The former category of studies has indicated that melting is never a large term of the surface energy budget in these glaciers, and minor changes to energy losses and gains can result in large changes to melt and ablation. One form of this sensitivity is the presence of microclimates along vertical cliffs that form the termini of these glaciers (Chinn, 1987; Lewis and others, 1999) and in sheltered and debris-rich topographic basins on the glacier surfaces (Johnston and others, 2005; Bagshaw and others, 2010; MacDonell and others, 2012). Statistical models have performed well at coarse spatial (drainage basin) and temporal (seasonal) scales, but introduce major uncertainty when applied outside of their calibration periods, due to changes in the underlying physical processes driving melt.

In previous papers, we have described a surface energybalance model that works well for the glaciers of the MDV (Hoffman and others, 2008, 2014). The model nicely reproduced observations of surface lowering, ice temperature and ice density when penetration of solar radiation into the ice is included and when subsurface meltwater is allowed to drain away (Hoffman and others, 2014). This work showed that ablation of glacier surfaces in the MDV is dominated by sublimation with rare events of surface melt. However, subsurface melt and drainage was comparatively common and important for the heat and mass balance at the modeled locations. 
In this paper, the model is applied across the ablation zones of the glaciers of Taylor Valley to determine whether the previous results and processes explain valley-wide mass-balance observations, generally, over 15 summers. After validating the model across the valley, we used it to investigate a change in ablation sensitivity that occurred midway through our period of study and inferred that modest and spatially variable changes in albedo, perhaps associated with deposition of windblown sediment, are the most likely cause. Finally, we assessed climate sensitivity of the MDV glaciers, considering changes to air temperature, ice albedo and wind speed.

\section{STUDY AREA AND MEASUREMENTS}

Taylor Valley is centrally located in the MDV adjacent to McMurdo Sound and is roughly $40 \mathrm{~km}$ long, oriented eastwest (Fig. 1). The western end of the valley is blocked by Taylor Glacier, an outlet glacier of the East Antarctic ice sheet; the eastern end is open to the ocean but a moraine blocks most streamflow from exiting the valley. The valley floor is primarily covered by sandy soils, punctuated by perennially ice-covered lakes and glaciers descending from the adjacent mountain ranges connected by short streams. Mean annual air temperature on the valley floor ranges from -23 to $-15^{\circ} \mathrm{C}$, with mean summer air temperatures a few degrees below freezing (Doran and others, 2002a). A prevalent feature of the MDV climate is intense downvalley drainage winds (often tens of $\mathrm{m} \mathrm{s}^{-1}$ ) which can adiabatically increase temperatures by $10^{\circ} \mathrm{C}$ or more within hours. These events are more common in winter than summer (Doran and others, 2002a; Nylen and others, 2004; Speirs and others, 2010).

Alpine glaciers, up to a few tens of $\mathrm{km}^{2}$ in area, flow from the adjacent mountains that border the valley. The ablation zones are generally bare ice all year, with episodic snow events in any season briefly ( $\sim$ week) covering the ice (Fountain and others, 1998, 2009). A strong climatic gradient follows the valley axis with warmer, drier and windier conditions inland (west) (Doran and others, 2002a; Nylen and others, 2004; Fountain and others, 2014) creating a rise in the equilibrium line at a rate of $30 \mathrm{~m} \mathrm{~km}^{-1}$ (Fountain and others, 1999a, 2006). While sublimation is the dominant form of ablation, melt can also be important, with the majority of melt occurring beneath the ice surface in the upper $20 \mathrm{~cm}$ of ice (Fountain and others, 1999b; Hoffman and others, 2014).

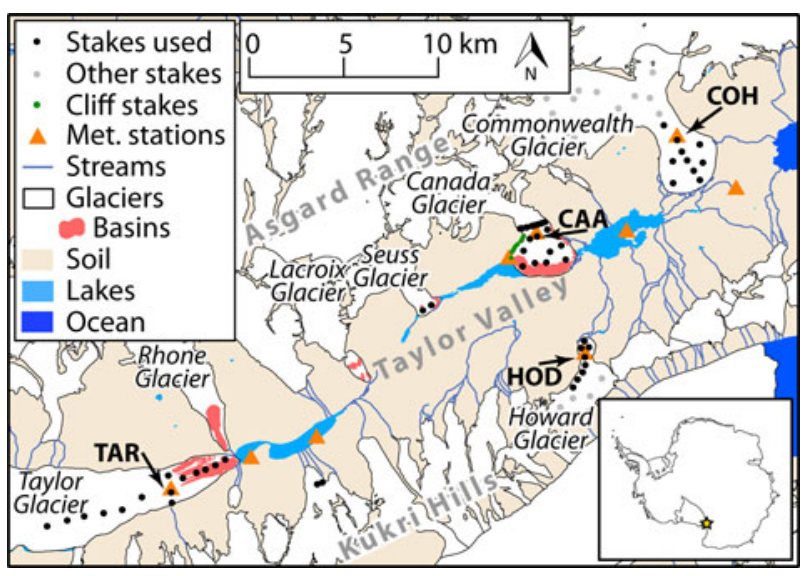

Fig. 1. Map of Taylor Valley.
A network of four on-glacier (designated CAA, TAR, HOD and $\mathrm{COH}$ ) and four off-glacier meteorological stations have measured air temperature, relative humidity, wind speed and direction, and incoming shortwave and longwave radiation across Taylor Valley at 15 min measurement intervals since the mid-1990s (Doran and others, 2002a, b; Nylen and others, 2004) (Fig. 1). During the study period, average summer (November-January) air temperature ranged from $-6.0^{\circ} \mathrm{C}$ in 2006 to $-3.9^{\circ} \mathrm{C}$ in 2001 at the Taylor Glacier AWS (Fig. 2). The 2001 summer had substantially greater degree-days above freezing than other years.

Seasonal mass-balance measurements were collected on four glaciers in the valley using a network of stakes on each glacier (Fountain and others, 2006). The fundamental measurements at each stake are the change in glacier surface height against a stake drilled into the glacier and surface density from which mass balance is calculated. Also, limited measurements of the mass balance of the vertical terminal cliffs of Canada and other glaciers were recorded (Lewis and others, 1999; Fountain and others, 2006) (Fig. 1).

In this study, a subset of 53 ablation stakes measured from 1995 through 2011 and restricted to the ablation zones of the glaciers were used to test the model (Fig. 1; Table 1). Because the surface mass-balance measurements assume a constant ice density (Fountain and others, 2006) but substantial mass loss occurs beneath the ice surface and lowers ice density (Hoffman and others, 2014), in this work we considered the stake measurements to record surface lowering and compared this with modeled surface lowering after accounting for changes in ice density due to the drainage of subsurface melt.

\section{DISTRIBUTED ABLATION MODEL DESCRIPTION}

For runoff prediction we applied a spatially distributed version of a one-dimensional (1-D) surface energy-balance model used by Hoffman and others (2014), which has previously been described in detail (Liston and others, 1999; Hoffman and others, 2008; Hoffman, 2011). This model is composed of a surface energy balance and a subsurface heat and mass balance of the upper $15 \mathrm{~m}$ of the glacier, which includes the penetration of solar radiation and the

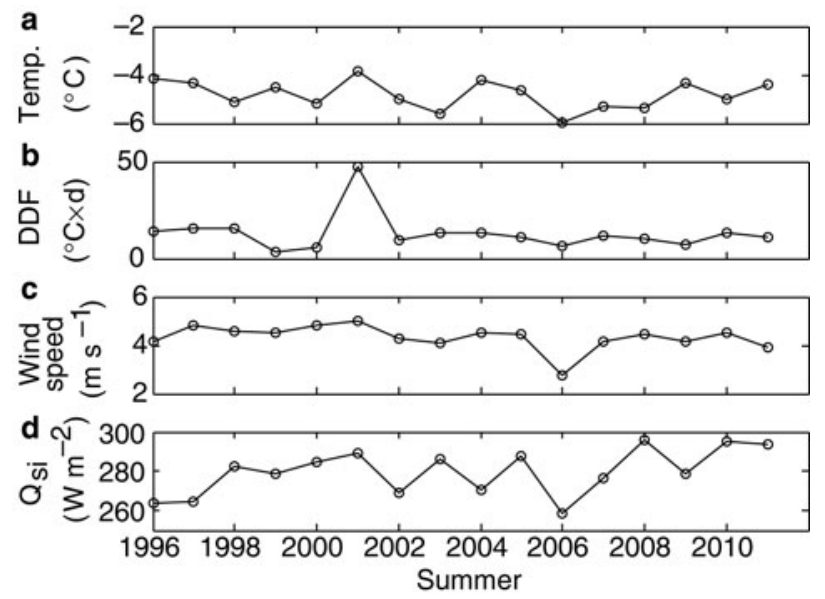

Fig. 2. Summer (November-January) meteorological variables at Taylor Glacier meteorological station: (a) Mean air temperature; (b) total degree-days above freezing; (c) mean wind speed; (d) mean incoming solar radiation. 
Table 1. Number of mass-balance stakes on the ablation zones of each glacier, not including terminal cliffs. Stake elevations are $m$ a.s.l.

\begin{tabular}{lccc}
\hline Glacier & Number of stakes & Minimum elevation & Maximum elevation \\
\hline Taylor & 14 & 518 \\
Canada & 22 & 90 & 304 \\
Howard & 8 & 352 & 149 \\
Commonwealth & 9 & 287 \\
\hline
\end{tabular}

drainage of subsurface melt. In the surface energy balance:

$$
\chi(1-\alpha) \mathrm{Q}_{\mathrm{si}}+\mathrm{Q}_{\mathrm{li}}+\mathrm{Q}_{\mathrm{le}}+\mathrm{Q}_{\mathrm{h}}+\mathrm{Q}_{\mathrm{e}}+\mathrm{Q}_{\mathrm{c}}=\mathrm{Q}_{\mathrm{m}},
$$

$\chi$ allocates a fraction of the net solar radiation at the surface (with the remainder forming the subsurface heating source term; see Eqn (2)), $\alpha$ is the albedo, $Q_{\text {si }}$ is the incoming shortwave solar radiation, $Q_{\mathrm{li}}$ is the incoming longwave radiation, $Q_{\mathrm{le}}$ is the emitted thermal radiation, $Q_{\mathrm{h}}$ is the sensible heat flux, $Q_{\mathrm{e}}$ is the latent heat flux, $Q_{\mathrm{c}}$ is the heat conduction in the ice and $Q_{\mathrm{m}}$ is the energy available for melt, calculated as a residual. All heat flux terms have units, $\mathrm{W} \mathrm{m}^{-2}$, and a positive sign is the energy directed toward the surface. $Q_{\text {si }}$ $\alpha$ and $Q_{\mathrm{li}}$ are supplied from observations, and the terms that cannot be directly measured $\left(Q_{\mathrm{le}}, Q_{\mathrm{h}}, Q_{\mathrm{e}}, Q_{\mathrm{c}}\right)$ are cast in a form that leaves surface temperature, $T_{0}$, as the only unknown (Liston and others, 1999).

The conductive heat flux, $Q_{c}$, in Eqn (1) is calculated using a 1-D heat-transfer equation,

$$
\rho_{\mathrm{i}} C_{\mathrm{p}} \frac{\partial T_{\mathrm{i}}}{\partial t}=\frac{\partial}{\partial z}\left[k \frac{\partial T_{\mathrm{i}}}{\partial z}\right]-\frac{\partial q}{\partial z}
$$

where $T_{\mathrm{i}}(\mathrm{K})$ is the ice temperature, $z(\mathrm{~m})$ is the vertical coordinate, $t(\mathrm{~s})$ is time, $\rho_{\mathrm{i}}$ is the density of glacier ice $\left(\mathrm{kg} \mathrm{m}^{-3}\right), C_{\mathrm{p}}(\mathrm{J}$ $\left.\mathrm{kg}^{-1} \mathrm{~K}^{-1}\right)$ is the specific heat of the ice and $q\left(\mathrm{~W} \mathrm{~m}^{-2}\right)$ is the net solar radiative flux. The thermal conductivity of the ice is dependent on the water fraction and ice temperature and density (Hoffman and others, 2008). When ice below the surface layer melts, a water fraction within each grid cell is accounted for, and any additional melt beyond $10 \%$ water fraction is assumed to instantly drain and run off out of the modeled domain (Hoffman and others, 2014). We refer readers to previous studies (Liston and others, 1999; Hoffman and others, 2008, 2014; Hoffman, 2011) for details of the model formulation, including the description of the latent and turbulent fluxes and calculation of the net solar radiative flux within the ice.

The model was spatially distributed using a $250 \mathrm{~m}$ grid, with a second $250 \mathrm{~m}$ grid representing the vertical cliffs along the glacier termini. Specifically, the 1-D (vertical) surface energy-balance model was applied independently at each model grid cell of the domain. The initial ice temperature profile for each grid cell was isothermally equal to the local mean annual air temperature, and the model spinup period was 14 years of model time (once through the entire length of our input data time-series) to generate a realistic profile of internal ice temperatures.

The topography for the grids was generated using a $40 \mathrm{~m}$ resolution digital elevation model (DEM) acquired through the SPOT 5 SPIRIT program (Korona and others, 2009), which was subsequently downsampled to $250 \mathrm{~m}$. The modeling domain was restricted to the typically snow-free ice of the glacier ablation zones to predict runoff. Snowmelt on the glaciers is rare due to the high albedo and lower air temperatures away from the warm soils. In the accumulation zone when snowmelt does occur, it refreezes at depth, producing no runoff (Fountain and others, 1998). The model was applied with an hourly time step for the period 1996-2011. We focused on model results for summer, with summer seasons defined by the dates of stake measurements, which typically occurred in early November and late January (a $\sim 69 \mathrm{~d}$ duration). For convenience, we refer to each summer by the starting year (e.g. the 1996/97 austral summer is referred to as 1996).

The model requires three adjustable parameters: surface roughness $\left(z_{0}\right)$, effective ice grain radius $\left(r_{\text {eff }}\right)$ and solar radiation surface fraction $(\chi)$, which partitions the incident solar radiation into that absorbed at the surface and that transmitted into the ice. Appropriate values for the three parameters were determined by Hoffman and others (2014) at three glacier sites in Taylor Valley using 1680 Latin hypercube samples of the parameter space. The optimal values found for the three sites were similar, with some differences in $z_{0}$ that were explained by differences in observable roughness features. The values of the parameters quantified by Hoffman and others (2014) were used in the present application except for $z_{0}$, which was varied as glacier surface roughness varied. Specifically, we use values of $r_{\text {eff }}=0.064 \mathrm{~mm}$, $\chi=22 \%$ and $z_{0}$ of $0.05 \mathrm{~mm}$ for smooth glacier ice and 1.0 $\mathrm{mm}$ for areas with rough topographic basins. These values yielded the smallest averaged RMSE for the three previous calibration sites.

Model inputs included air temperature, relative humidity, wind speed, incoming shortwave and longwave radiation and ice albedo. We generated hourly gridded weather data from the data of the eight meteorological stations in Taylor Valley using spatial interpolation by the quasi-physically based meteorological model MicroMet (Liston and Elder, 2006). Before processing with MicroMet, the weather data were averaged to $1 \mathrm{~h}$ time intervals and wind speeds were adjusted to $3.0 \mathrm{~m}$ height, the nominal height of the instruments, assuming a neutral density profile to compensate for changing instrument height as the on-glacier meteorological stations ablated out of the ice. The shortwave radiation scheme in MicroMet was modified to account for topographic shading (Dozier and Frew, 1990) and to use measurements of incoming solar radiation to estimate cloudiness following parameterizations of the relation between clearness index and diffuse fraction (Liu and Jordan, 1960; Skartveit and Olseth, 1987; Skartveit and others, 1998), and accounting for surface slope (Jonsell and others, 2003) and direct and diffuse components (Hock and Holmgren, 2005). Additionally, to extrapolate our measurements of incoming longwave radiation across Taylor Valley, we used parameterizations for clear-sky and all-sky emissivity of Konzelmann and others (1994), after assessing the performance of over 20 published longwave radiation parameterizations (summarized 
by König-Langlo and Augstein, 1994; Pirazzini and others 2001; Flerchinger and others, 2009). Finally, MicroMet was run separately for the vertical cliffs along the glacier termini to capture topographic effects on radiation for these surfaces. Details of the modifications to MicroMet and its application to Taylor Valley are described by Hoffman (2011).

Ice albedo is a particularly important model input. To reduce noise in albedo time-series and to provide more spatially representative values, we used the average of daily-averaged albedo measured at two glacier meteorological stations (CAA and TAR) that are well below their glacier's equilibrium lines. The $\mathrm{HOD}$ and $\mathrm{COH}$ meterological stations also measure albedo but are located at the equilibrium line and the glacier surfaces there are typically snow covered. During the summer of 2001, bare ice was exposed at the equilibrium line of $\mathrm{HOD}$ and $\mathrm{COH}$, revealing that ice albedo on these glaciers is $\sim 0.05$ less than at CAA and TAR, so we lower albedo on these glaciers accordingly. More detailed information on spatial variations of ice albedo was not available. Snow events, though infrequent, dramatically change the albedo and reduce runoff (Fountain and others, 2010; Hoffman and others, 2014). We ignore snow events entirely, for two reasons. First, the meteorological stations are all located relatively high on the ablation zones, and snowfall at those elevations is more frequent than at lower elevations where runoff is more abundant. Second, comparisons between model versions that ignored and included snow events showed a negligible difference in overall model skill.
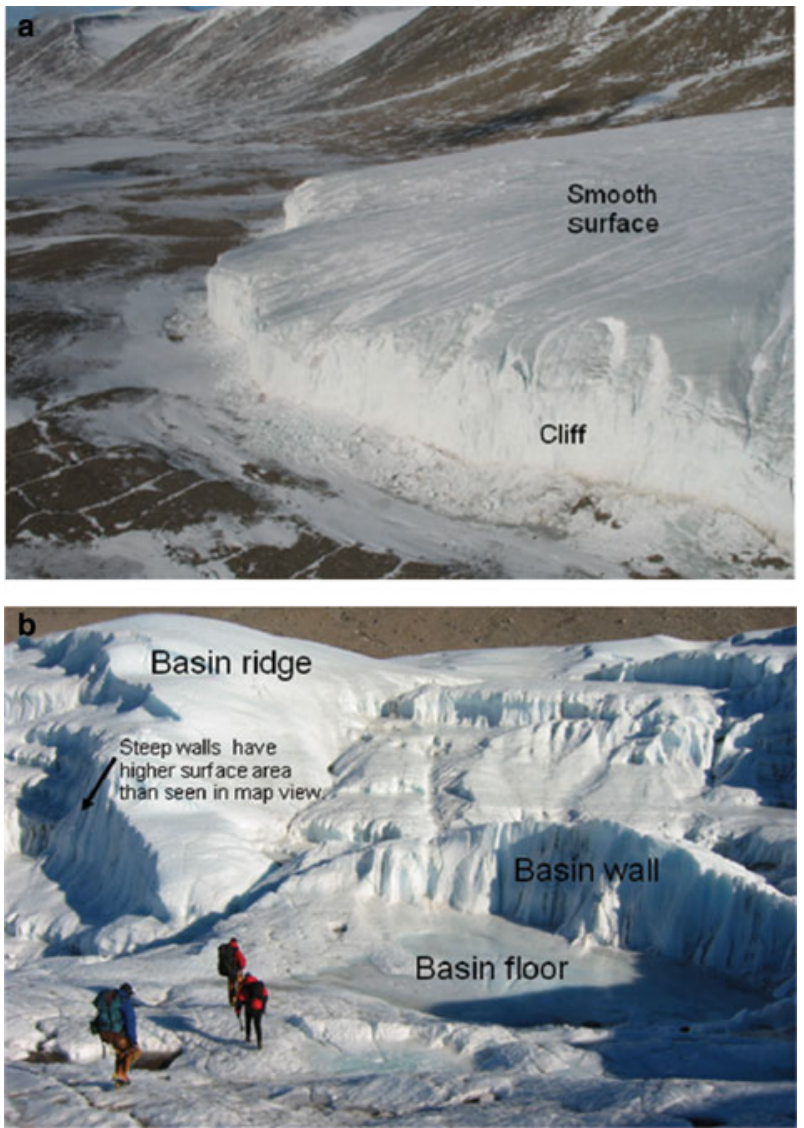

Fig. 3. Photographs demonstrating the topographic morphologies modeled. (a) Smooth surface and cliff topographic morphologies (Howard Glacier). The cliff here is $\sim 25 \mathrm{~m}$ high. (b) Basin morphology showing floors, walls and ridges (Taylor Glacier).
Previous studies of MDV glaciers have identified large spatial variations in surface energy balance and melt production due to local microclimates. To account for these variations, we established three submodels, one for smooth glacier surfaces, one for basins with complex relief and one for terminal cliffs.

\subsection{Smooth surfaces}

The surface morphology and ice composition over most of the ablation zones are dominated by gently sloping, smooth surfaces composed of bubbly, white ice (Fig. 3a) (Hoffman and others, 2008, 2014). The surface is pockmarked with cryoconite holes and refrozen fractures composed of bubblefree blue ice covering about $4-6 \%$ of the area of these surfaces in Taylor Valley (Fountain and others, 2004), which we ignore for this application. Concentrated sediment is found within cryoconite holes, but rare on the glacier surface. In these locations, we applied the distributed meteorological data without adjustment and used the smaller surface roughness value $\left(z_{0}=0.05 \mathrm{~mm}\right)$.

\subsection{Basins}

Basins are locally rough terrain incised into the once smooth glacier surface. These melt-formed features are found near the glacier termini and exhibit vertical cliffs up to $20 \mathrm{~m}$ high, rumpled basin floors and narrow passages between basins downstream (Fig. 3b). This topography is common to many glaciers, including Taylor, Rhone, LaCroix, Suess and Canada glaciers (Johnston, 2004) (Fig. 1). Basins are associated with abundant sediment and rock debris from a variety of possible sources - medial moraines on Taylor Glacier, windblown sand and silt on Canada Glacier or rock avalanche debris elsewhere. The basins are hypothesized to develop from this debris, which causes local melting, a more energetically efficient ablation process that results in the formation of local depressions (Lewis, 2001; Johnston and others, 2005). Compared with the surrounding smooth surfaces, the depressions more effectively trap solar radiation due to multiple reflections from the walls and floor, and experience lower wind speeds, which reduce turbulent exchange (MacClune and others, 2003). These differences increase local temperature and humidity, further favoring melt. In addition, the accumulation of sediment and refreezing meltwater (forming 'blue ice') in the basin reduces the albedo of the basin floor. In some cases, the meltwater forms ice-topped pools $10-50 \mathrm{~m}$ in diameter (Bagshaw and others, 2010). Enhanced melt occurs within the basins and melt areas enlarges them at the expense of the surrounding smooth surfaces. We do not differentiate the morphology, orientation or causal mechanism of channels and basins, and for simplicity we refer to all topographically rough regions as 'basins'.

The spatial distribution of basin terrain was mapped empirically, using the criteria of relief $>3 \mathrm{~m}$ within a $10 \mathrm{~m} \times$ $10 \mathrm{~m}$ area using a $2 \mathrm{~m}$ resolution DEM (US Geological Survey, 2012). This criterion roughly corresponds to slopes $>15^{\circ}$. The regions were manually revised to ensure that smooth surfaces with high slope were not included and that basin floors and intervening ridges with low slope were included. Within the areas delineated as basins, the topography was further divided into three components: floors, walls and intervening ridges (Table 2). Floors were 
Table 2. Summary of meteorological adjustments for the basin submodel

\begin{tabular}{lccccc}
\hline & $\begin{array}{c}\text { Area fraction } \\
\%\end{array}$ & Surface area & $\begin{array}{c}\text { Air temperature } \\
{ }^{\circ} \mathrm{C}\end{array}$ & \multicolumn{2}{c}{$\begin{array}{c}\text { Wind speed } \\
\%\end{array}$} \\
\hline Floors & 19 & - & +1.5 & -67 & -0.17 \\
Walls & 60 & $+20 \%$ & +0.5 & -33 & -0.065 \\
Ridges & 21 & - & +0.0 & -0 & -0.0
\end{tabular}

Notes: Area fractions and surface area adjustment are calculated from $2 \mathrm{~m}$ gridded lidar data. Basin floor adjustments are the average of adjustments measured by Lewis (2001) and Johnston (2004). Basin ridges are unadjusted, and basin wall adjustments are the average of the floors and ridges.

identified by slopes $<15^{\circ}$ with concave-up curvature (calculated over distances of $20 \mathrm{~m}$ ), walls were identified by slopes $>15^{\circ}$ and ridges were identified by slopes $<15^{\circ}$ that did not meet the curvature criterion for floors.

To model basin floor microclimate we parameterized the difference between climate on the smooth surface and in the basins. Simultaneous meteorological measurements in basins and adjacent surfaces on Canada Glacier (Lewis, 2001) and on Taylor Glacier (Johnston, 2004) (Table 2) show that air temperature in the basin is warmer by $1.5^{\circ} \mathrm{C}$ (when incoming solar radiation is greater than $50 \mathrm{~W} \mathrm{~m}^{-2}$ ), and wind speed is slower by $67 \%$ (Table 2 ). The basin surface is also rougher, $z_{0}=1.0 \mathrm{~mm}$ (Hoffman and others, 2014). Drag-partition modeling of similarly sized ( $10 \mathrm{~m})$ dome features in the ablation zone of the Greenland ice sheet by Smeets and van den Broeke (2008) also indicated $z_{0}=\sim 1 \mathrm{~mm}$ for ice features of this scale. The meteorological adjustments for the walls applied were midway between the basin floors and smooth surfaces (Table 2). Johnston (2004) found wall albedo on Taylor Glacier to be 0.065 less than the smooth surfaces. To calculate the melt volume from the walls, the planimetric area covered by basin walls is increased by $20 \%$, based on average aspect ratios, to account for the wall area (Fig. 3b). No meteorological adjustment was applied to the ridges between basins.

\subsection{Terminal cliffs}

Near-vertical cliffs define the glacier edge in the ablation zone (Fig. 3a). Although the cliffs make up a small fraction of the ablation area, they can generate a substantial fraction of total meltwater runoff. For example, on Canada Glacier the terminal cliffs account for $2 \%$ of the total ablation area but up to $15-20 \%$ of the runoff (Lewis and others, 1999). To model cliff melt a separate $250 \mathrm{~m}$ resolution model domain was used to describe the geometry of the cliffs. Length and mean aspect were calculated for each $250 \mathrm{~m}$ segment using the $2 \mathrm{~m}$ resolution DEM. For simplicity we assumed all cliffs are vertical (Fountain and others, 1998) with a uniform height of $25 \mathrm{~m}$ (Fountain and others, 2006). We ignored cliff ablation due to calving, a mechanical rather than energy-balance process. MicroMet calculations of incoming shortwave and longwave radiation for the cliffs were used unaltered within the melt model, but the output for air temperature and wind is changed by $+0.5^{\circ} \mathrm{C}$ and $-32 \%$, respectively, according to field measurements (Lewis and others, 1999; Pettit, personal communication; summarized in Hoffman, 2011) (Table 3). The model used a constant ice albedo on the cliffs of 0.55 (Lewis and others, 1999; Hoffman, 2011) because snow does not accumulate on the vertical surfaces, and cliff surface roughness $\left(z_{0}\right)$ was set to $0.1 \mathrm{~mm}$ (Lewis and others, 1999). However, the abrupt vertical shape of cliffs violates a fundamental assumption of the bulk aerodynamic theory of a flat, homogeneous surface that extends for $\sim 10^{2} \mathrm{~m}$ (Brutsaert, 1982; Lewis and others, 1999), making this an uncertain parameter.

\section{RESULTS}

\subsection{Smooth surfaces}

The model reproduced observed summer surface lowering at the 53 mass-balance stakes across the ablation zones, performing best on Taylor and Canada Glaciers, where the meteorological stations are located well within the ablation zone (Figs 4 and 5). In most years surface lowering was almost entirely attributed to sublimation and surface melt was typically negligible. Even in the warmest summer of 2001 when ablation was an order of magnitude larger than previous or following years little surface melt occurred at most stakes. Subsurface melt, however, made a common and substantial contribution to ablation across the smooth surfaces in all but the coolest summers. Unlike on temperate glaciers, observations and model ablation showed little elevational gradient except in the warmest summers. This may be due to the large component of sublimation, which has a weaker elevation dependence than melt, a lack of a spring snow cover and migrating snow line and the patchy albedo of these icy surfaces. Although not the focus of the paper, winter ablation was also well predicted (not shown) because the only ablation process was sublimation.

Close inspection of the model results reveals mismatches that provide insight into the model shortcomings. In cool, low-ablation summers (e.g. 1996 and 2000), the model overestimated ablation at the highest elevations; this is most apparent on Commonwealth and Howard Glaciers. This may be due to snow accumulation near the glacier

Table 3. Summary of meteorological adjustments and parameters for each submodel

\begin{tabular}{|c|c|c|c|c|}
\hline & Air temperature & Wind speed & Albedo & $z_{0}$ \\
\hline Smooth surfaces & - & - & - & $0.05 \mathrm{~mm}$ \\
\hline Basins & $+0.1^{\circ} \mathrm{C}$ & $-14 \%$ & -0.052 & $1 \mathrm{~mm}$ \\
\hline Cliffs & $+0.5^{\circ} \mathrm{C}$ & $-32 \%$ & 0.55 & $0.1 \mathrm{~mm}$ \\
\hline
\end{tabular}




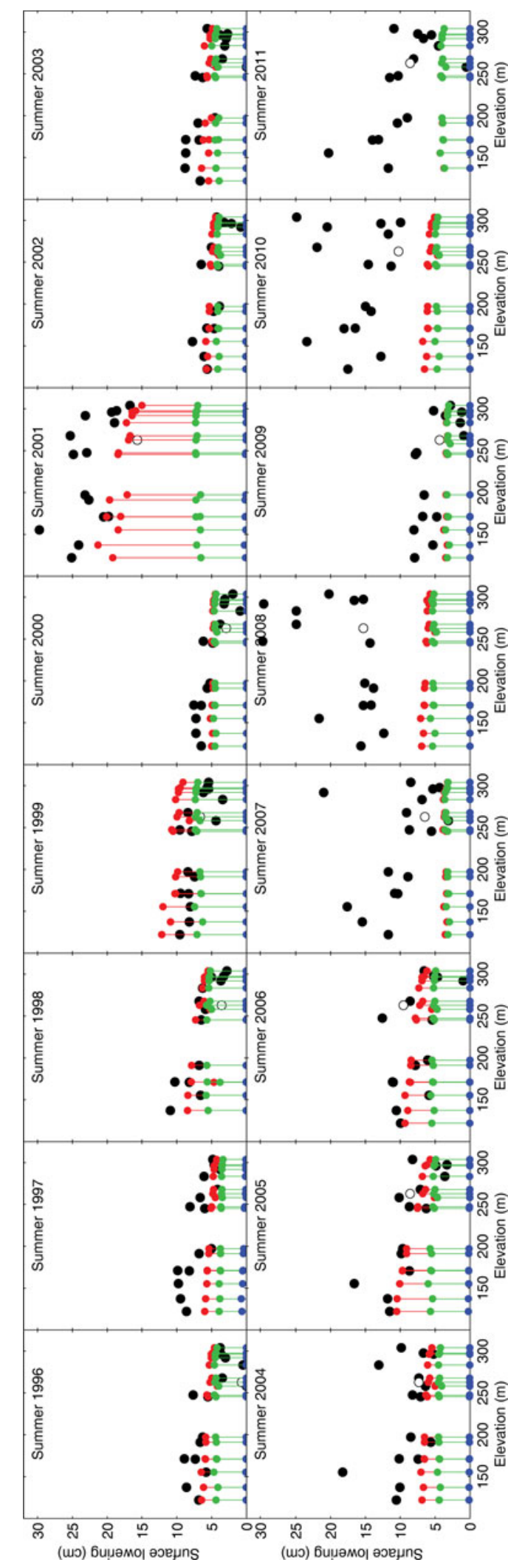

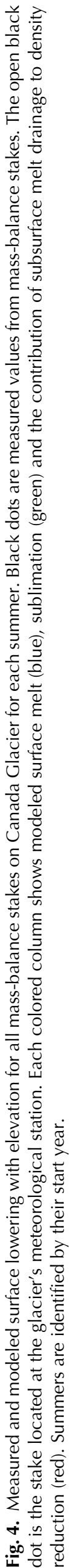

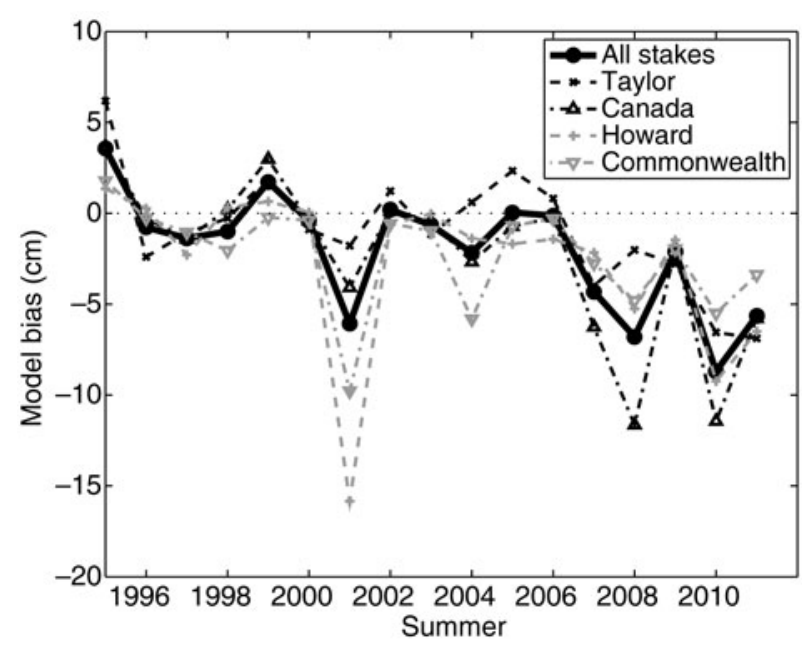

Fig. 5. Mean model error (i.e. bias) in surface lowering for all stakes on each glacier in each summer.

equilibrium lines, which was not included in the model. During the warmest summer of 2001, the MDV experienced anomalously large glacier melt and associated stream runoff (Doran and others, 2008). In that year the model captures surface lowering well across all elevations on Taylor Glacier, slightly underpredicts surface lowering on Canada Glacier and severely underpredicts on both Howard and Commonwealth Glaciers. The spatial pattern of these errors suggests a process missing from the model that affects the Lake Fryxell and Hoare basins but not the Lake Bonney basin. Interestingly, starting in the summer of 2007, model predictions underestimated both the magnitude and variability in ablation for all stakes (Fig. 5). Taylor Glacier was the least affected and Canada Glacier the most. This suggests a process change not included in the model, which is investigated in Section 5.2.

\subsection{Cliffs}

The analysis of model performance on terminal cliffs was restricted to the cliff segments on the west side of Canada Glacier where long-term (11 years) stake measurements exist. The number of stake observations in a given season varies between 2 and 11, but most seasons have at least 5 . Because of high spatial variability in the observations, we averaged all stake measurements for each summer and compared the cliff-wide average of surface lowering with the averaged modeled results (Fig. 6). The cliffs have measured summer surface lowering rates that are typically about $\sim 50 \%$ larger than for the adjacent smooth surface of Canada Glacier (Figs 4 and 6a).

Modeled surface lowering on the terminal cliffs matched observations well. In contrast to the smooth surfaces, model results indicated that surface melt makes the largest contribution to surface lowering on the cliffs during summer, with sublimation also being important. Subsurface melt is a much smaller fraction of cliff surface lowering than it is for the smooth glacier surfaces. However, in the extreme melt season of 2001, subsurface melting was the largest contributor to surface lowering on the cliffs.

Due to uncertainty in the appropriate value of the surface roughness, $z_{0}$, to use for the cliffs, we additionally validated the cliff model using observations of surface lowering during the winter mass-balance season, when sublimation is the 

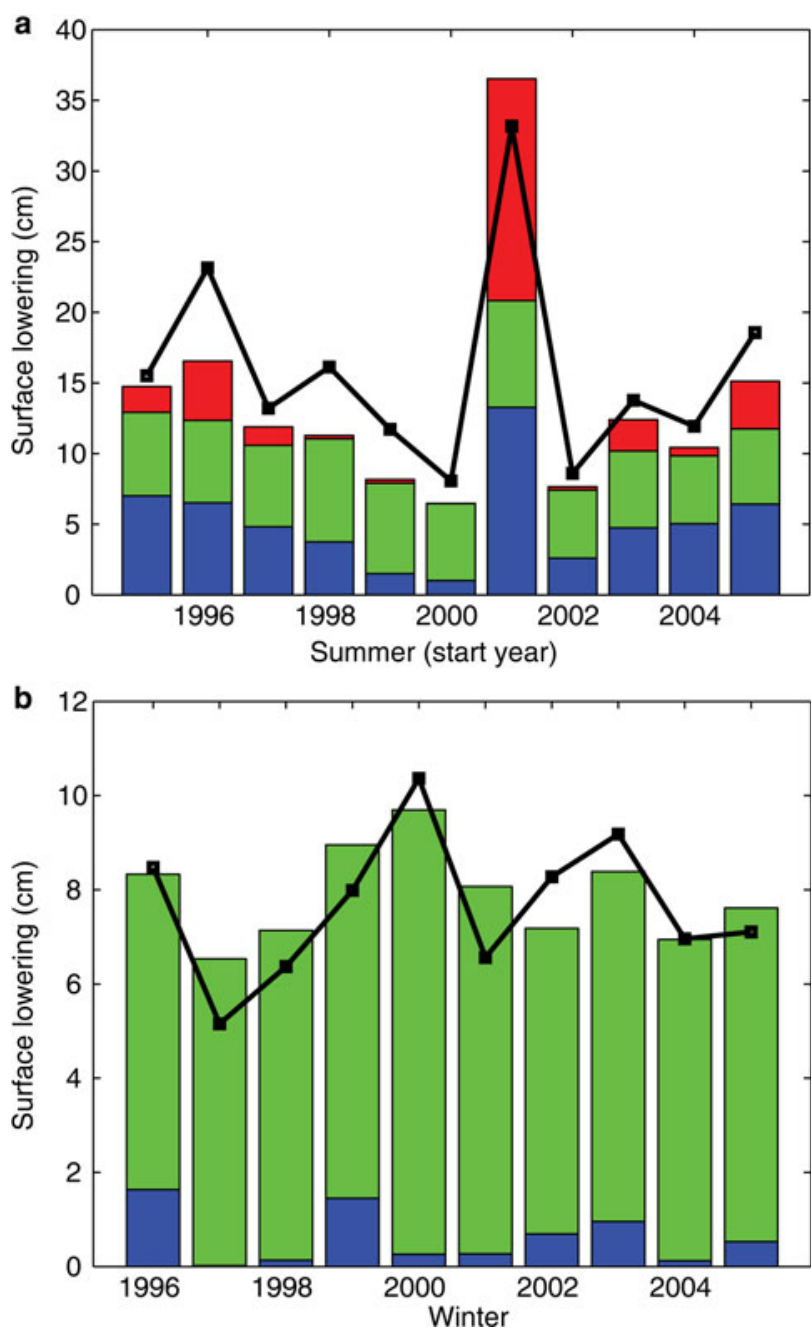

Fig. 6. Seasonal surface lowering along Canada Glacier westside cliff. (a) Summer. (b) Winter. Black curve is measured ablation averaged over 3-11 cliff stakes each season. Stacked bars show modeled ablation. Blue is surface melt, green is sublimation and red is the contribution of subsurface melt drainage to density reduction.

primary ablative process (Fig. 6b). Model results for both summer and winter seasons suggested that the $z_{0}$ value of $0.1 \mathrm{~mm}$ chosen is appropriate for the cliffs. The model also demonstrated that melt is a non-trivial contribution to cliff melt during the winter mass-balance season.

\subsection{Specific mass loss from different ablative processes}

Using the ablation model we mapped individual components of summer ablation and ablation patterns on specific surfaces across the glaciers of Taylor Valley (Fig. 7). Sublimation exhibits a smooth spatial trend across the valley, with little dependence on elevation. Close inspection shows that sublimation is reduced in the basins, as expected, due to the wind shadow caused by the depressions. Sublimation across the valley shows a marked break between the western $(>6$ $\mathrm{cm}$ w.e. summer $\left.{ }^{-1}\right)$ and eastern $\left(<6 \mathrm{~cm}\right.$ w.e. summer $\left.{ }^{-1}\right)$ basins (Fig. 7a). This partition corresponds to the separation between the Bonney basin and Hoare/Fryxell basins, respectively, caused by the presence of a large $700 \mathrm{~m}$ hill (Nussbaum Riegel) in the center of the valley. Higher wind speeds, drier atmosphere and warmer temperatures are found in the Bonney basin (Fountain and others, 1999a). Variations in sublimation from summer to summer are minor $(< \pm 25 \%)$ and the spatial patterns are consistent. Sublimation rates exceeded melt rates over most of the glaciers' surfaces, except at the lowest elevations and in the basin areas.

Subsurface melt had a marked dependence on elevation, while spatial trends were less evident. The lack of spatial trends suggests that local influences control melt production, such as basins. Although the area covered by the basins is a small fraction of the glaciers' ablation areas, the modeled melt rates in the basins were two to ten times larger than on neighboring smooth surfaces (Figs $7 b$ and $c$ and $8 a$ ). While we were unable to validate the modeling of the basin areas directly, this result is consistent with previous studies that found ablation rates up to an order of magnitude larger in areas with topographic basins (Chinn, 1987; Lewis, 2001; Johnston and others, 2005). No melt was predicted on high-elevation ablation zones in the western part of the valley (gray regions in Fig. 7b-d).

Cliff melt was highly variable. Melt on north-facing cliffs was often two to ten times greater than on adjacent smooth surfaces, and for south-facing cliffs the ratio was inverted (Figs $7 \mathrm{~b}$ and $\mathrm{d}$ and $8 \mathrm{~b}$ ). Cliffs with east and west aspects were modeled to melt at similar rates to smooth surfaces. Model results indicate that cliffs differed from horizontal surfaces in that surface melt formed a substantial fraction of ablation on cliffs. The ice surface of cliffs is warmed relative to the upper glacier surface by a microclimate of increased air temperature, reduced wind speed and increased longwave radiation (due to a large fraction of incoming longwave radiation from warm, dark soils). Additionally, direct solar radiation is absent from these vertical surfaces much of the day, which reduces subsurface melting. While our results contrast with previous work suggesting that cliffs melt at rates substantially higher than smooth surfaces (Lewis and others, 1999), our modeling here included all the cliffs in the valley over an 11 year period, whereas the Lewis and others report was a site-specific study. Consistent with our model results, Lewis and others (1999) also identified increased longwave radiation and decreased shortwave radiation on cliffs as key components of the cliff surface energybalance.

\section{DISCUSSION}

\subsection{Assessment of model skill}

In most summers, the model has low bias in surface lowering $(<3 \mathrm{~cm})$ when model skill is averaged over all stakes on the smooth surfaces of each glacier (Fig. 5). This shows that the model works well beyond the three point locations considered previously (Hoffman and others, 2014), and provides a good constraint on melt production before applying the model for prediction of glacier runoff in future work. In particular, Taylor and Canada Glaciers were modeled very well, with lower model skill at Howard and Commonwealth Glaciers. Additionally, for the one area with long-term observations of cliff ablation (west side of Canada Glacier), the model predicted the magnitude of ablation on the vertical cliffs well (Fig. 6).

The somewhat poorer model performance on Howard and Commonwealth Glaciers may result from two issues. First, the model was calibrated on Canada and Taylor Glaciers 

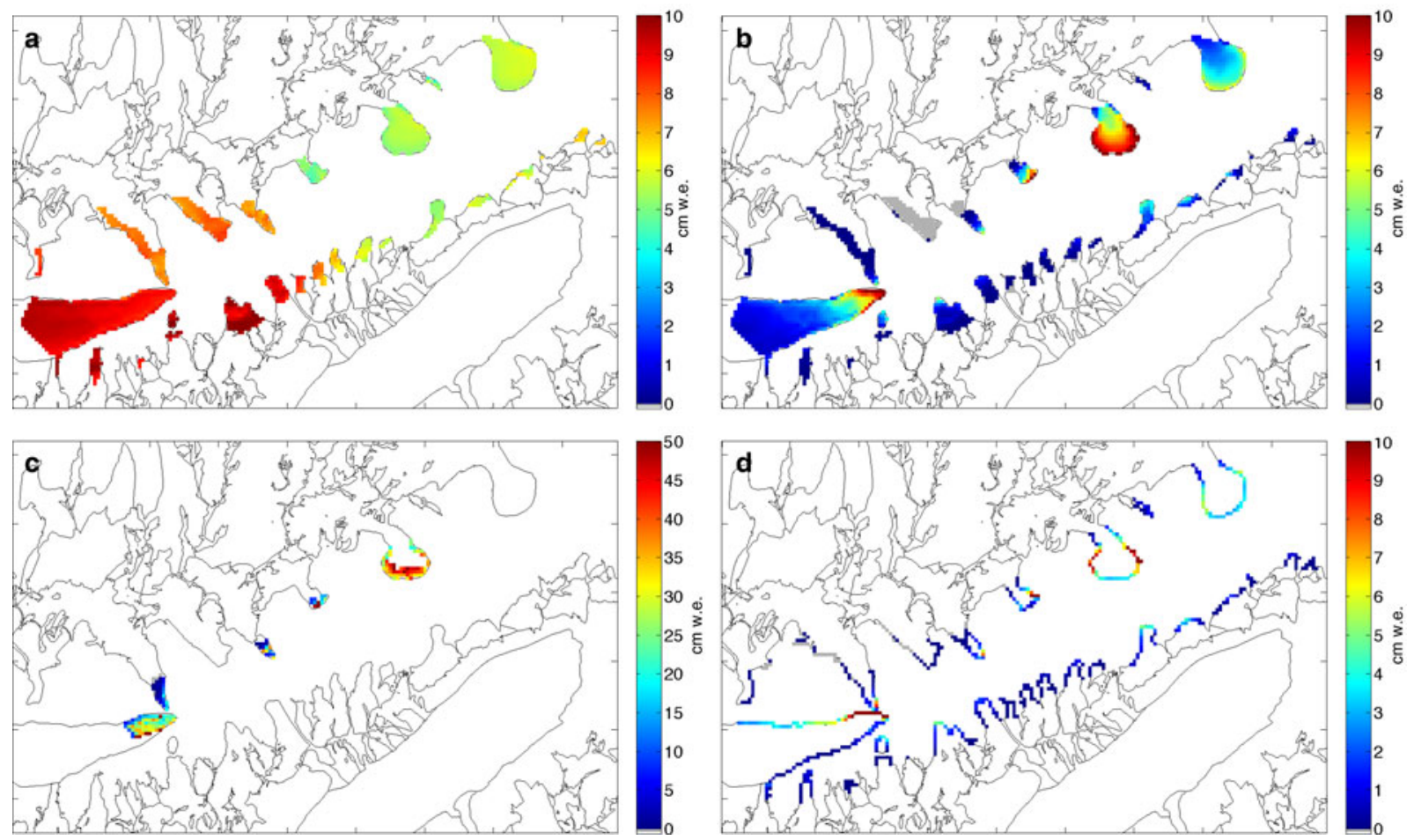

Fig. 7. Average summer specific mass loss ( $\mathrm{cm}$ w.e.) for glacier ablation zones in Taylor Valley from various ablative processes. (a) Sublimation on smooth surfaces. (b) Melt on smooth surfaces. (c) Melt from basins. (d) Melt from cliffs. Melt includes both surface melt and drainage of subsurface melt. Note the change in color-bar range in (c). Tick marks are at $5 \mathrm{~km}$ intervals.

(Hoffman and others, 2014) and therefore optimized for those glaciers. Second, and perhaps more important, both Howard and Commonwealth Glaciers receive more snow (Fountain and others, 2009), which the model ignores. Furthermore, as mentioned previously, the albedo applied to these glaciers was extrapolated from Canada and Taylor Glaciers.

While the model generally does well reproducing the magnitude of ablation, it does less well reproducing the spatial and temporal variability in the stake observations, as can be seen in a Taylor diagram (Taylor, 2001) (Fig. 9). The model has a correlation coefficient of 0.49 with stake observations when all glaciers and summers are considered (Fig. 9, open red circle), but this correlation is not statistically significant. Additionally, RMS deviation is large $(7.4 \mathrm{~cm} / 0.87$ normalized) and spatio-temporal variations in the model (i.e. standard deviation) are about half of that in the observations (Fig. 9, open red circle). We attribute some of this discrepancy to uncertainty in stake observations of surface lowering; though the precision of individual stake measurements is estimated at $3 \mathrm{~mm}$ based on multiple measurements at each stake (Fountain and others, 2006), we observe much greater variability of the order of $\mathrm{cm}$ between neighboring stakes due to local microclimatic effects at each stake (Fountain and others, 2006; Hoffman and others, 2014) (e.g. Fig. 4). Thus, uncertainty in the representativeness of individual stake measurements limits the model's ability to reproduce the spatio-temporal variability in observations. Nonetheless, we find these metrics of model skill useful in comparing different spatial and temporal subsets. For example, it is clear that the model reproduces variability in ablation best at Taylor Glacier and worst at Howard Glacier (red circles, Fig. 9).

Despite the overall good model performance, for the last 5 years of the record (summer 2007 through 2011) model bias increased up to $10 \mathrm{~cm}$ (Fig. 5). The bias was largest at Canada Glacier, but was evident at all four glaciers. Additionally, the
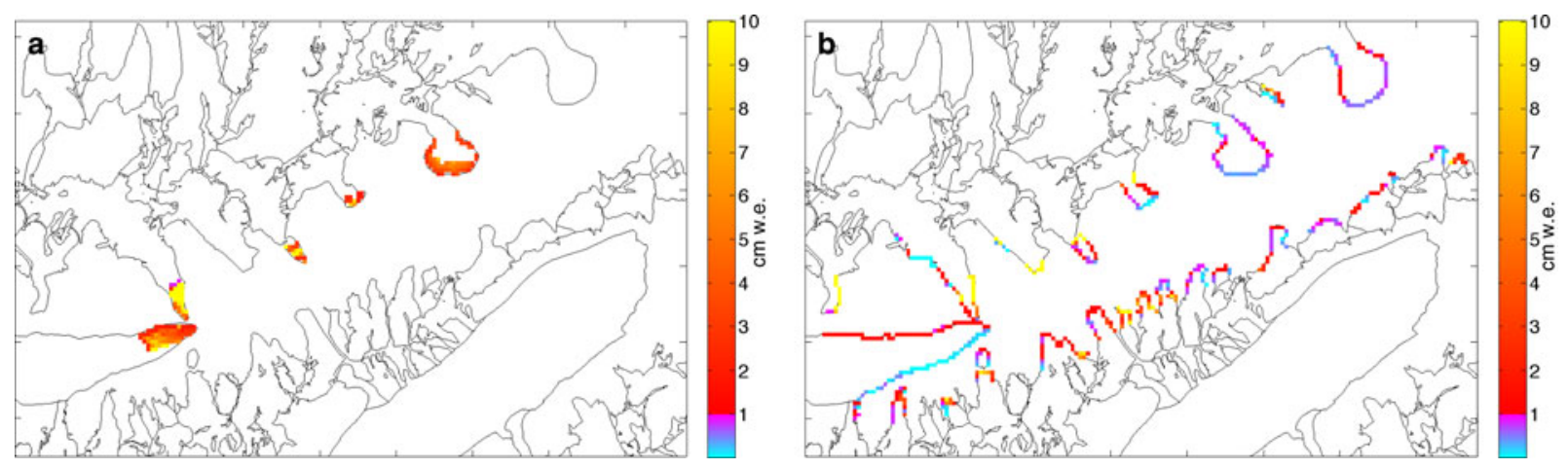

Fig. 8. Relative mass loss from melt between different surfaces. (a) Ratio of melt in basins to co-located smooth surfaces. (b) Ratio of melt from cliffs to co-located smooth surfaces. 


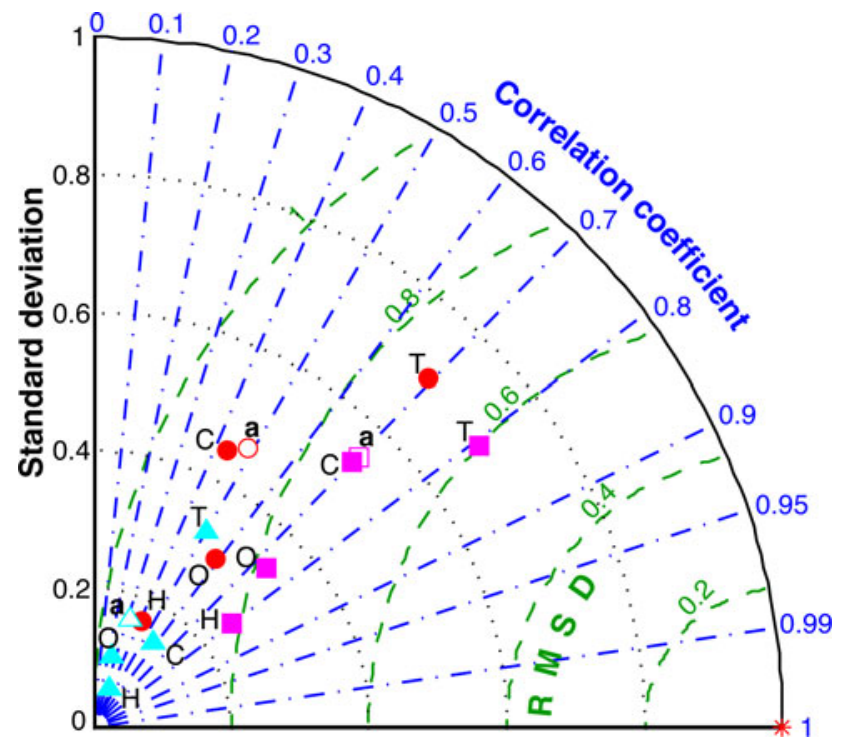

Fig. 9. Taylor diagram (Taylor, 2001) showing model correlation, centered RMS difference, and standard deviations compared with stake observations of surface lowering. Red circles represent the entire 1996-2011 study period, pink squares represent the 19962006 time period and light blue triangles represent the 2007-11 time period. Each glacier studied is indicated by letters: T, Taylor; $\mathrm{C}$, Canada; $\mathrm{H}$, Howard; O, Commonwealth; a, all four glaciers combined (emphasized by open symbols). The statistics are calculated using summation over space (all stakes in a specified region) and time (all summers in a specified time period). The statistics have been normalized and non-dimensionalized to allow the different time and space subsets to be plotted on a single plot. Thus, the location of the red star indicates perfect agreement with observations.

2001 summer was biased low at all glaciers, particularly for Howard and Commonwealth Glaciers. The model was never biased high, suggesting that there may be an unknown process or an unknown change in conditions leading to enhanced ablation. This was likely from enhanced melt, as sublimation rates need to increase by nearly an order of magnitude to explain the discrepancy.

Furthermore, the higher spatial variability in measured ablation values (which also propagates into the model bias) during these summers suggests a shift to more spatial heterogeneity in ablation. This is demonstrated by the higher skill for the 1996-2006 period (pink squares in Fig. 9) relative to the 2007-11 period (light blue triangles in Fig. 9) on the Taylor diagram, and the higher spatial variability in ablation can clearly be seen qualitatively in Figure 4 for the summers 2007-11. Localized melting is a likely cause of spatially variable ablation.

Because the model performed well in the first part of the data record, we hypothesize a change in physical conditions occurred. We favor this explanation because temporal observations of the glacial surfaces were limited to four point measurements (meteorological stations) and the meteorological variables were interpolated over long (tens of $\mathrm{km}$ ) distances. However, the meteorological environment slowly varies across space (except for the basins) and cannot explain the increased variability in ablation. One of the most sensitive parameters in the energy-balance equation is surface albedo, which can be quite variable over time and space. We hypothesize that the albedo observations used to force the model have become less
Table 4. Summary of perturbed forcing experiments. Each forcing was perturbed independently of the others

\begin{tabular}{ll}
\hline Forcing & Perturbations simulated \\
\hline Albedo & -0.18 to +0.06 by intervals of 0.02 \\
3 m air & $-6,-4,-2,-1.5,-1.0,-0.5,+0.5,+1.0,+1.5$, \\
temperature & $+2.0,+4.0,+6.0{ }^{\circ} \mathrm{C}$ \\
Wind speed & -50 to $+50 \%$ by intervals of $10 \%$
\end{tabular}

representative over time. The sensors themselves were recalibrated at 2 year intervals (Doran and others, 2002a) precluding sensor performance as the cause. Because of the location of the meteorological stations on Commonwealth and Howard Glaciers, albedo measurements were used from only Taylor and Canada Glaciers both of which are at relatively high elevation, and fail to sample the glaciers closest to the coast. Given this obvious source of uncertainty, we performed a series of model runs with perturbed albedo values (Table 4) and compared the modeled ablation from each run with the measurements, to determine whether the magnitude of albedo required to eliminate model bias made physical sense.

Results showed that for the first 11 years of record, only small adjustments to the observed albedo $( \pm 0.03)$ were necessary to eliminate model bias in most years (Fig. 10a). A
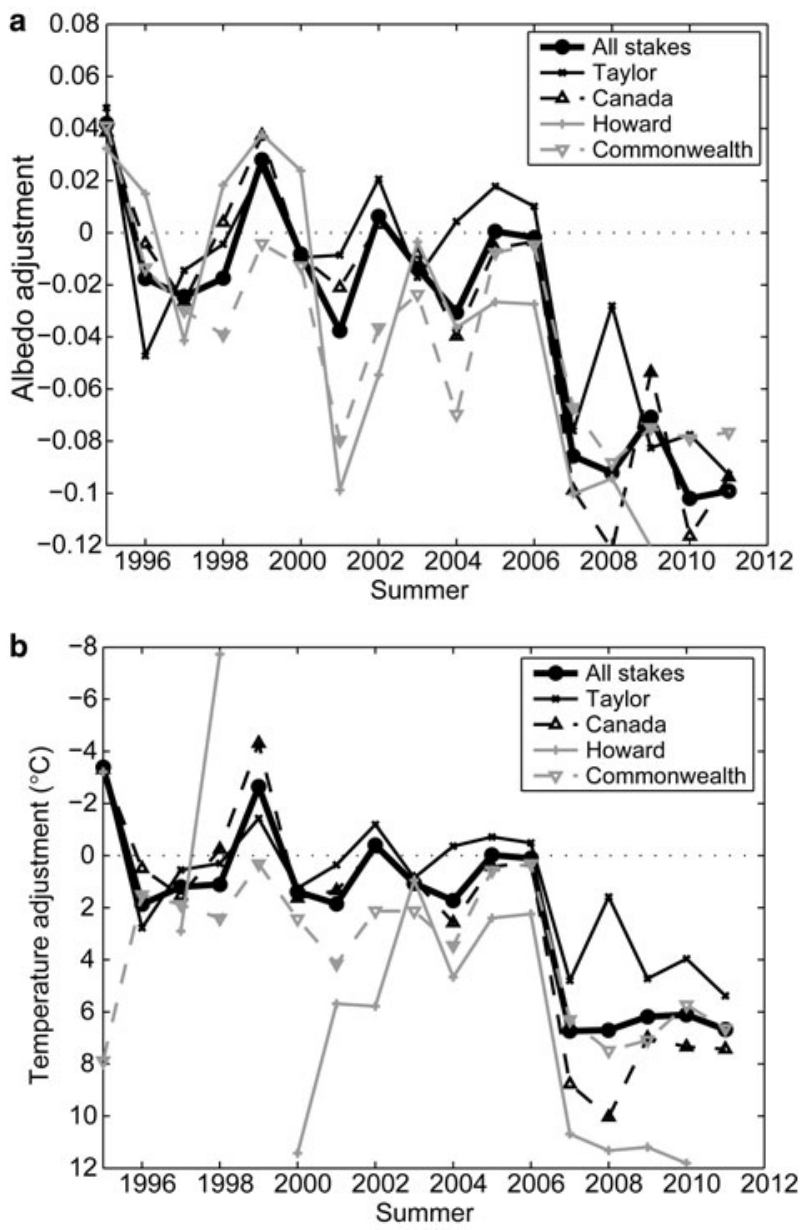

Fig. 10. Adjustments to (a) albedo and (b) temperature needed to remove model bias in surface lowering for each summer. The vertical axis in (b) is inverted for easier comparison with (a). 
lower albedo was required for both Commonwealth and Howard Glaciers, particularly in 2001. These small adjustments are within the uncertainty of the sensors. Reported uncertainty in glacier albedo from point observations using paired broadband pyranometers is $\sim \pm 2-5 \%$ (e.g. Brock and others 2000; Jonsell and others 2003; Azzoni and others 2014), a range comparable with our observational uncertainty.

Over the last 5 years of the record, the required albedo adjustment to remove model bias was substantially greater: -0.09 averaged over all glaciers. This adjustment is well within observed variability on glaciers elsewhere. On temperate glaciers, ice albedo can vary spatially and temporally by up to 0.30 , even after accounting for variations in debris cover, elevation and accumulated melt (Brock and others, 2000; Klok and others, 2003; Azzoni and others, 2014), highlighting challenges in representativeness when using point observations of albedo. Ice albedo on polar glaciers is less variable due to less melt and debris, but we commonly see contemporaneous differences in ice albedo of 0.10 between the four glacier meteorological stations in Taylor Valley. Even for the apparently stationary first half of the record, uncertainty in the albedo measurements can translate to model error of $>30 \%$ of surface lowering, indicating the need for more accurate and extensive observations of albedo on these glaciers.

For the 'big melt' summer of 2001, a large albedo reduction ( - 0.09) was required at Howard and Commonwealth Glaciers similar to that for all the glaciers in the last 5 years of record. However, a large reduction of albedo was not required by the model at the locations of the meteorological stations on Canada or Taylor Glaciers where albedo is measured. Investigation of the stake record shows that the stakes co-located with these two automatic weather stations exhibit a relatively low surface lowering in 2001 and for the period 2007-11 relative to nearby stakes. This suggests the sediment distribution and its albedo reduction is patchy, supporting anecdotal field observations.

To test whether changing air temperature could explain the same ablation variability and change over the last 5 years of record, another series of model runs were performed (Table 4; Fig. 10b). For the first 11 years of the record, temperature adjustments of a few degrees removed the model bias in each summer, but for the final 5 years the model required a temperature increase of $\sim 7^{\circ} \mathrm{C}$. Such a large adjustment is clearly unrealistic, particularly given the dense network of temperature observations (Fig. 1), supporting our interpretation that changes in albedo are responsible.

Aeolian sediment transport in the MDV is relatively common (Šabacká and others, 2012; Gillies and others, 2013). MacDonnell and others (2012) describe an annual cycle of winter föhn winds (Nylen and others, 2004; Speirs and others, 2010) depositing sediment on Wright Lower Glacier in neighboring Wright Valley, which enhances summer melt. The sediment distribution is uneven, resulting in heterogeneous melting across the glacier surface. There is less evidence for this annual cycle in Taylor Valley; however, infrequent high-speed wind events $\left(>20 \mathrm{~m} \mathrm{~s}^{-1}\right)$ transport sediment in Taylor Valley (Šabacká and others, 2012), which is deposited on the glaciers. We suggest that the lowered albedo for the period 2007-11 results from aeolian transported sediment. The model bias was strongest at Canada Glacier (Fig. 5), as was the increased spatial variability in surface lowering seen in stake observations. This suggests an effect strongest at this location consistent with the observed sand-dune on the west side of Canada Glacier and the intrusion of the glacier across the valley floor, creating an obstacle to downvalley transport (Šabacká and others, 2012). Whether the sustained increase in melt over the final 5 years of the record was a result of a single, exceptional event or a series of repeating smaller events, is unclear. The twice-yearly mass-balance measurements preclude detection of specific events. Aeolian sediment flux measurements showed large, but not extreme, sediment fluxes for 2007 (Šabacká and others, 2012).

The addition of windblown sediment to the glacier surfaces is certainly a plausible explanation for the magnitude of albedo change inferred from this analysis. Low concentrations of sediment and aerosols have a strong effect on the albedo of ice and snow (Wiscombe and Warren, 1980a; Warren, 1984; Gardner and Sharp, 2010; Dadic and others, 2013b; Azzoni and others, 2014). Ice is even more sensitive to low concentrations of sediment than snow, with an albedo reduction of 0.01 reached with a mass fraction of ash of $10 \mathrm{ppb}$ for Antarctic blue ice similar to that found on Taylor Valley glaciers (Dadic and others, 2013b). Dadic and others (2013a, b) show that increasing ash concentration on Antarctic blue ice from 1 to $10 \mathrm{ppm}$ reduces ice albedo by $\sim 0.10$. Assuming ash has a similar absorption spectrum to the dust and sediment found in Taylor Valley, this seems a plausible magnitude of sediment loading for an exceptional sediment-loading event. The albedo parameterization of Gardner and Sharp (2010) indicates a soot concentration of $1.9 \mathrm{ppm}$ would reduce ice albedo by 0.10 relative to clean ice; given our lack of knowledge of background impurity concentrations on Taylor Valley glaciers, these two estimates are not inconsistent. Azzoni and others (2014) found that increasing the areal fraction of debris cover from 0 to $25 \%$ on a temperate glacier in the Italian Alps reduces ice albedo by 0.10 . However, the albedo of debris-free ice on that glacier (0.35) was substantially lower than that of the ice found in Taylor Valley (0.56), precluding a direct transfer of this relationship.

It should be noted that large wind events that would deposit sediment on the glaciers would also directly affect melt by substantially altering the turbulent fluxes. While föhn wind events substantially raise air temperature (Nylen and others, 2004), the increased sublimation they generate inhibits melt (Hoffman and others, 2008; Bliss and others, 2011). There is no indication that a change in frequency or intensity in summertime föhn wind events occurred around 2007 (Fig. 2), but even if that were the case, the weather data forcing the model would capture the change. Thus, the increase in model bias starting in 2007 is likely due to sediment deposited by wind events, and not the wind events themselves.

\subsection{A hypothesis for unmodeled ablation variability}

One possible explanation for the strong change in ablation despite limited measurements of a change in albedo is the incorporation of sediment within the ice weathering crust (Hoffman and others, 2014) as it develops. Desert dust and ash typically absorb preferentially in the blue end of the visible spectrum (Wiscombe and Warren, 1980a; Dadic and others, 2013b). These are the wavelengths that penetrate beyond the first few $\mathrm{cm}$ of ice (Wiscombe and Warren, 1980b; Brandt and Warren, 1993; Liston and others, 1999) 
into the depths where most melting on MDV glaciers occurs (Hoffman and others, 2014). Thus, these sediments would be particularly efficient at enhancing below-surface melt. Previous studies have shown that, in snow, impurities impact albedo less when located beneath the surface, but still affect the absorbance of shortwave radiation (Aoki and others, 2000; Grenfell and others, 2002). Similarly, for the ice cover on MDV lakes, Jepsen and others (2010) found that subsurface sediment melts through the ice faster than sediment on the surface because surface sediment loses heat to the atmosphere, supporting our idea of increased melt efficacy of sediment at depth.

We speculate that sediment from a rare high-flux sediment transport event (or events) was added to the glacier surfaces sometime in 2006 or 2007, with the greatest concentration occurring locally on Canada Glacier. The sediment was incorporated below the ice surface during normal seasonal weathering and crust development (MacDonell and others, 2012). Below the surface this sediment continued to enhance melting, but at that point it was contributing to the subsurface melt that is dominant on these glaciers (Hoffman and others, 2014). Further, below the surface the sediment was not as visible and possibly had a muted effect on broadband surface albedo. Because of the low melt rates and minimal supraglacial flow on these glaciers, this sediment was not washed away as it occurs quickly on temperate glaciers (Brock and others, 2000; Jonsell and others, 2003; Azzoni and others, 2014), and it has generated a multi-year effect.

A detailed investigation of sediment distribution, concentration and optical properties is necessary to assess this hypothesis, but if correct, this suggests that sediment loading associated with exceptional wind events has the potential to change MDV glacier melt rates and associated streamflow as much as a large $\left(\sim 7^{\circ} \mathrm{C}\right)$ change in climate. For reference, Coupled Model Intercomparison Project Phase 5 projections for summer air temperature at 2100 relative to present over Antarctic land areas under representative concentration pathway 6 (RCP6) are substantially smaller than this: +0.7 to $+3.7^{\circ} \mathrm{C}$ (Christensen and others, 2013). (RCP6 is one of the midrange greenhouse gas concentration trajectories defined by the Intergovernmental Panel on Climate Change, and is consistent with anthropogenic greenhouse gas emissions peaking in 2080 and then declining. It is used here as a well-described reference for projected temperature change for the Antarctic.) Such an effect may help to explain the existence of large paleolakes presumed to fill the MDV valleys during the Last Glacial Maximum (Hall and others, 2010) despite air temperatures $8{ }^{\circ} \mathrm{C}$ lower than present at nearby Taylor Dome (Steig and others, 2000). In addition to cooler temperatures, the nearby Taylor Dome ice core also records a near order-of-magnitude increase in aerosols within the ice during the last glacial period, as has commonly been observed across the ice sheets (Steig and others, 2000).

\subsection{Surface mass-balance sensitivity}

Previous studies have shown that the glaciers of Taylor Valley are quite sensitive to small changes in energy balance (Lewis and others, 1998; Johnston, 2004; Ebnet and others, 2005; Hoffman and others, 2008; Hoffman, 2011). In summer, solar radiation warms the ice and the winds cool the ice and small changes in the energy-balance variables can shift ablation from energy-costly sublimation to energy-efficient melt. However, no previous study has explored the sensitivity of ablation on these glaciers to the various forcing factors. To understand the hydrology of the valleys, past, present and future, and to infer paleoclimatic conditions from geologic, hydrologic and biologic legacies found in the valley requires understanding of glacial ablation response to changes in environmental factors.

We used our model to assess the sensitivity of ablation to changes in air temperature, albedo and wind speed. The sensitivity of glacier surface mass balance to air temperature can be assessed by perturbing the forcing of a calibrated surface mass-balance model by \pm 1 K (Oerlemans and Fortuin, 1992; Oerlemans and others, 1998; Cuffey and Paterson, 2010). The standard approach is to apply the model analysis over an entire year, either at a point (specific surface massbalance) or averaged over an entire glacier (average specific surface mass balance). This approach can be extended to other climate parameters such as albedo and wind speed (e.g. Bintanja, 1989; Gerbaux and others, 2005; Anslow and others, 2008).

We consider only summer ablation restricted to the ablation zones of the glaciers because of its implications for summer meltwater production. Winter ablation on MDV glacier ablation zones is relatively insensitive to air temperature, and ablation is entirely through sublimation (Hoffman and others, 2008). To facilitate comparison with glaciers in other regions, we present our results as traditional surface mass-balance sensitivity. Note we considered ablation to include sublimation, surface melt and drainage of subsurface melt, (m w.e.) as opposed to surface lowering, which was used earlier. The ranges of parameter perturbations applied is described in Table 4 and Figure 11.

Averaged over the Taylor Valley glacier ablation zones, surface mass-balance sensitivity to temperature was $\sim-0.02 \mathrm{mw}$.e. $\mathrm{K}^{-1}$ for small temperature perturbations (Fig. 11a). Sensitivity was fairly uniform across the four glaciers considered but is strongest at Taylor Glacier and weakest at Howard Glacier. For all glaciers, as temperature decreased beyond a couple of degrees $<0{ }^{\circ} \mathrm{C}$, surface mass balance became much less sensitive to temperature changes $\left(\sim 0.001 \mathrm{~m}\right.$ w.e. $\left.\mathrm{K}^{-1}\right)$. This large change in sensitivity was due to the elimination of melt on the smooth surface of these glaciers, leaving only the much weaker sensitivity of sublimation to temperature. Conversely, sensitivity increased as temperature increased above the current climate; at a temperature increase of $6 \mathrm{~K}$ the sensitivity more than doubled to $\sim 0.05 \mathrm{~m}$ w.e. $\mathrm{K}^{-1}$. A perturbation of more than a few degrees has questionable predictive value but the sensitivity increase indicates a transition to the melt-dominated summer environment found on subpolar and temperate glaciers.

Typical surface mass-balance sensitivity to temperature on temperate glaciers is in the range -0.4 to $-1.4 \mathrm{~m}$ w.e. $\mathrm{K}^{-1}$, with maritime glaciers typically having higher sensitivity than continental glaciers (Oerlemans and Fortuin, 1992; Oerlemans and others, 1998; Braithwaite and Zhang, 2000; Cuffey and Paterson, 2010). Subpolar glaciers are less sensitive, with values around $-0.1 \mathrm{mw}$.e. $\mathrm{K}^{-1}$ (Oerlemans and others, 1998; Cuffey and Paterson, 2010). Reported values in the Antarctic appear to be restricted to the relatively temperate South Shetland Islands, where there is stronger sensitivity than found here: $-0.6 \mathrm{~m}$ w.e. $\mathrm{K}^{-1}$ (Jonsell and others, 2012), $-0.3 \mathrm{~m}$ w.e. $\mathrm{K}^{-1}$ (Braun and Hock, 2004), $-0.1 \mathrm{~m}$ w.e. $\mathrm{K}^{-1}$ (Bintanja, 1989). Our values are more similar to those on Mount Kilimanjaro, Tanzania, -0.05 to $-0.10 \mathrm{~m}$ 

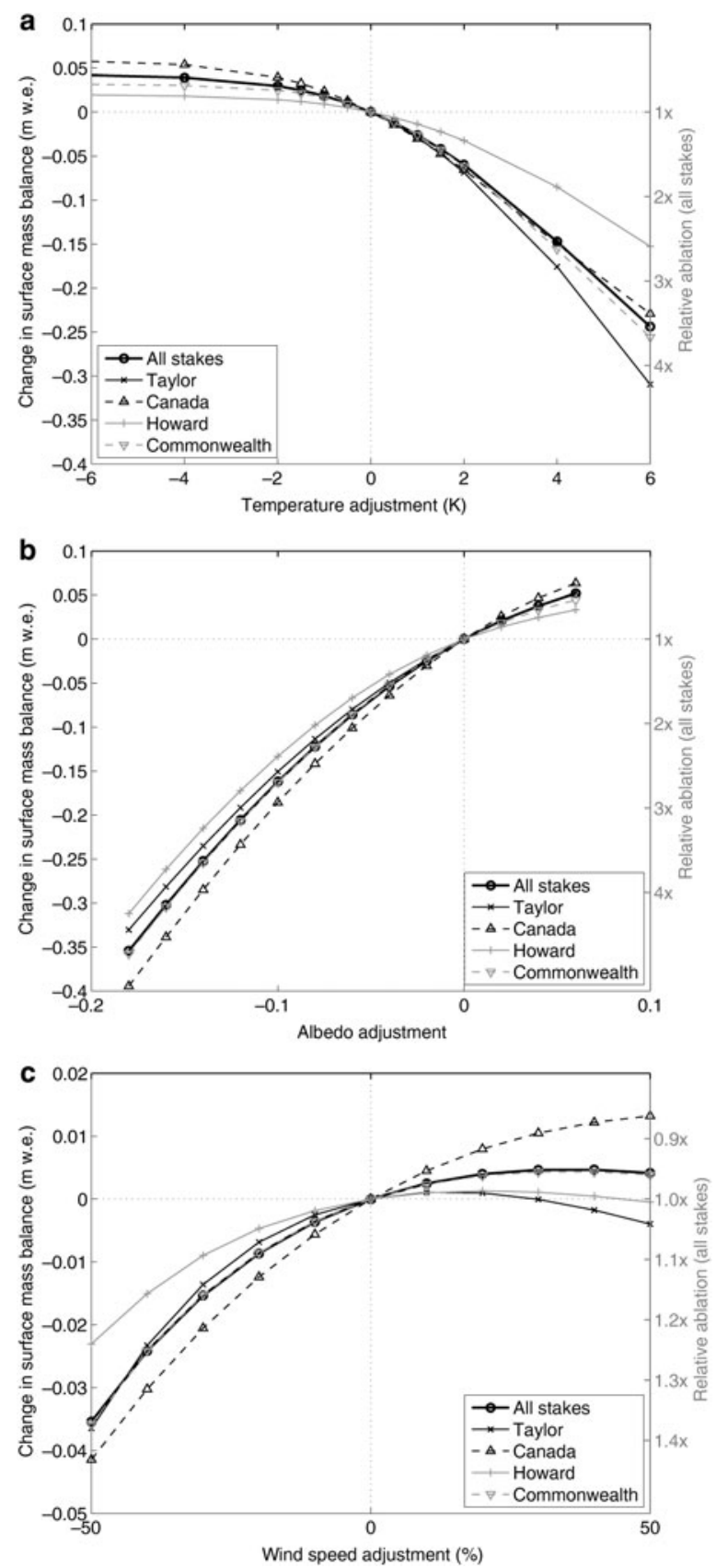

Fig. 11. Sensitivity of summer ablation to changes in (a) temperature, (b) albedo and (c) wind speed, averaged over the stakes on each glacier. Note the difference in $y$-axis scale in (c).

w.e. $\mathrm{K}^{-1}$ (Mölg and others, 2008). This is not surprising because the energy balance of ice on Kilimanjaro is very similar to that in Taylor Valley (Hoffman and others, 2008). The Taylor Valley glaciers have the weakest sensitivity to temperature that we are aware of, highlighting their extreme continentality and very low melt rates. And while the absolute sensitivity is extremely small, the relative sensitivity for these glacier ablation zones is large; a $1 \mathrm{~K}$ change in temperature changes ablation by $23 \%$.

For small changes in albedo, we found a surface massbalance sensitivity of +0.011 mw.e. per 0.01 change in albedo, with little difference between glaciers (Fig. 11b). Therefore, a 0.02 decrease in albedo has a similar effect on surface mass balance to increasing air temperature by $1 \mathrm{~K}$. These sensitivities are smaller than that for Morteratschgletscher, Switzerland, of +0.018 mw.e. per
0.01 change (Klok and Oerlemans, 2002). Because the ice albedo on Morteratschgletscher is substantially lower (0.34) than that of the MDV glaciers (0.60), a unit change in albedo there corresponds to a larger change in net shortwave radiation; this also accounts for the different sensitivities among the MCM glaciers, with Canada Glacier having a lower overall albedo than Taylor Glacier. A related comparison is that of ablation sensitivity to changes in net shortwave radiation. For Antarctic environments such sensitivities have been estimated at $-0.005 \mathrm{~m}$ w.e. $\%^{-1}$ to $-0.009 \mathrm{~m}$ w.e. $\%^{-1}$ for glaciers on the South Shetland Islands (Bintanja, 1989; Jonsell and others, 2012). If we convert our findings based on albedo changes to changes in net shortwave radiation, we find a similar sensitivity, $-0.004 \mathrm{~m}$ w.e. $\%^{-1}$. The slightly smaller sensitivity in Taylor Valley is likely due to some net shortwave energy lost to heating the nearsurface ice, which typically loses heat to the cooler atmosphere and deeper ice. In the other locations discussed, summer air temperature is typically above freezing, keeping the glacier surface at or near the melting temperature and allowing all or most net shortwave energy to go to melting.

Finally, we assessed surface mass-balance sensitivity to wind speed (Fig. 11c). For small perturbations of wind speed, increasing wind speed increases the surface massbalance (i.e. decreases ablation) at a rate of $+0.0003 \mathrm{~m}$ w.e. $\%^{-1}$. The positive sign reflects the cold, dry conditions there, such that the turbulent fluxes typically remove heat from the ice surface (Hoffman and others, 2008, 2014), and therefore increasing the wind speed removes more energy that may otherwise be available for melt. Though sublimation increases under such a situation, the rate of ablation for a given energy loss associated with sublimation is one-eighth that of melting. Three of the four glaciers show an interesting non-monotonic response where once increasing wind speed minimizes melt, further increasing wind speed increases ablation through enhanced sublimation. Overall, these results contrast with most other studies that find increasing wind speed lowers surface mass balance (increases ablation). On temperate glaciers, wind speed sensitivity is two orders of magnitude larger: $-0.05 \mathrm{~m}$ w.e. $\%^{-1}$ on South Cascade Glacier, Washington, USA (Anslow and others, 2008), and $-0.04 \mathrm{~m}$ w.e. $\%^{-1}$ at low elevations in the French Alps (Gerbaux and others, 2005). For the South Shetland Islands an intermediate magnitude of $-0.0035 \mathrm{mw}$.e. $\%^{-1}$ was assessed by Bintanja (1989).

These results show that glacial ablation is most sensitive to albedo, air temperature and then wind speed. However, our simple analysis ignores the complex spatio-temporal characteristics of wind in the MDV (Nylen and others, 2004; Speirs and others, 2010, 2013), as well as complexities in the sensitivity of turbulent fluxes to wind speed (Dadic and others, 2013a). Specifically for our field conditions, basins are a good example of this complexity. The basin floor is often characterized by a lower albedo compared with the surrounding smooth surfaces. The lower albedo and multiple reflections of solar radiation within the basin not only more efficiently trap the solar radiation, but also warm the air. Because the basin acts as a wind shadow, the turbulent exchange with the cooler winds aloft is reduced, further trapping the heat and the increased humidity. These processes act together and increasingly favor melt over sublimation, allowing the basin to deepen faster than the surrounding smooth surfaces. 


\section{CONCLUSIONS}

We applied a spatially distributed surface energy-balance model across the ablation zones of the glaciers of Taylor Valley using gridded weather data from eight meteorological stations over a 16 year period. The model was previously calibrated to three summers at three points, and was tested against a network of 53 surface mass-balance stakes spread over four glaciers spanning $\sim 30 \mathrm{~km}$, which showed high model skill in reproducing observed surface lowering from stake measurements spatially averaged across the glaciers studied. The model does less well at reproducing spatiotemporal variability in the observations, partly because individual measurements are noisy. The best model performance was in the west part of Taylor Valley where snowfall and cloud cover were less frequent and ice albedo was more accurately measured. As identified previously, surface melt was rare across these glaciers, but melt beneath the surface was common (Hoffman and others, 2014).

Model results showed that areas with $\sim 10 \mathrm{~m}$ scale surface roughness (basins) had ablation and melt rates that were substantially higher (up to $10 \times$ ) than smooth glacier surfaces. In contrast, the vertical cliffs in which the glaciers terminate had either higher or lower ablation and melt rates than the adjacent horizontal surfaces. Cliff aspect controlled the differences, with north-facing cliffs having relatively high melt rates.

Unsurprisingly, glacier melt and ablation were sensitive to ice albedo, each 0.01 decrease in albedo having a similar effect to a $0.5 \mathrm{~K}$ increase in temperature. Sensor uncertainty in albedo observations could explain model error for most of the record. For the last 5 years of record, however, the model underpredicted ablation, which cannot be explained by sensor performance. Anecdotal evidence points to lower albedo and the model showed that a reduction of only 0.09 can explain this change, well within the natural variability of glacier surfaces. We attributed the albedo reduction to wind events that transport sediment from the valley floor to the glacier surfaces.

The ablation sensitivity to temperature was $\sim-0.02 \mathrm{~m}$ w.e. $\mathrm{K}^{-1}$, which is among the smallest magnitudes observed globally. This is due to the fact that surface heating on these polar glaciers is lost to both the colder atmosphere and colder ice at depth. The sensitivity of these glaciers to changes in wind speed was also small compared with other glaciers globally $\left(+0.0003\right.$ mw.e. $\left.\%^{-1}\right)$, and was opposite in sign to what is commonly observed because the turbulent fluxes typically remove heat from these glacier surfaces. Despite the relatively small response of ablation to the change in these factors, it must be appreciated that in summer the glaciers of Taylor Valley are on the cusp of melting such that small changes in the energy balance have profound effects on ablation and commonly these factors interact producing greater ablation (and melt) than any one factor alone.

These results highlight the need for more study on ice albedo processes and spatio-temporal variability on these glaciers. The unique climate sensitivity of these glaciers may help explain apparent higher melt rates during colder, glacial times, as well as suggest that these glaciers may have a complicated response to a changing climate in the future.

\section{ACKNOWLEDGEMENTS}

This work was funded by US National Science Foundation (NSF) Office of Polar Programs grants ANT-0423595 and
ANT-0233823 and the Earth System Modeling program of the Office of Biological and Environmental Research within the US Department of Energy's Office of Science. We thank two anonymous reviewers for constructive reviews and Scientific Editor Martyn Tranter and Chief Editor Jo Jacka for guiding the review process.

\section{REFERENCES}

Anslow FS, Hostetler S, Bidlake WR and Clark PU (2008) Distributed energy-balance modeling of South Cascade Glacier, Washington and assessment of model uncertainty. J. Geophys. Res., 113(F2), F02019 (doi: 10.1029/2007JF000850)

Aoki T, Aoki T and Fukabori M (2000) Effects of snow physical parameters on spectral albedo and bidirectional reflectance of snow surface. J. Geophys. Res., 105(D8), 10219-10236 (doi: 10.1029/ 1999JD901122)

Azzoni RS, Senese A, Zerboni A, Maugeri M, Smiraglia C and Diolaiuti GA (2014) A novel integrated method to describe dust and fine supraglacial debris and their effects on ice albedo: the case study of Forni Glacier, Italian Alps. Cryosphere Discuss., 8 (3), 3171-3206 (doi: 10.5194/tcd-8-3171-2014)

Bagshaw EA, Tranter M, Wadham JL, Fountain AG and Basagic HB (2010) Dynamic behaviour of supraglacial lakes on cold polar glaciers: Canada Glacier, McMurdo Dry Valleys, Antarctica. J. Glaciol., 56, 366-368

Bintanja R (1989) The local surface energy-balance of the Ecology Glacier, King George Island, Antarctica: measurements and modelling. Antarct. Sci., 7(3), 315-325

Bliss A (2005) Surface energy balance of the Taylor Glacier, Antarctica. In University of California International and Area Studies, Breslauer Symposium, (3), 24

Bliss AK, Cuffey KM and Kavanaugh JL (2011) Sublimation and surface energy budget of Taylor Glacier, Antarctica. J. Glaciol., 57(204), 684-696 (doi: 10.3189/002214311797409767)

Braithwaite RJ and Zhang Y (2000) Sensitivity of mass balance of five Swiss glaciers to temperature changes assessed by tuning a degree-day model. J. Glaciol., 46(152), 7-14

Brandt RE and Warren SG (1993) Solar-heating rates and temperature profiles in Antarctic snow and ice. J. Glaciol., 39(131), 99110

Braun M and Hock R (2004) Spatially distributed surface energy balance and ablation modelling on the ice cap of King George Island (Antarctica). Global Planet. Change, 42(1-4), 45-58 (doi: 10.1016/j.gloplacha.2003.11.010)

Brock BW, Willis IC and Sharp MJ (2000) Measurement and parameterization of albedo variations at Haut Glacier d'Arolla, Switzerland. J. Glaciol., 46(155), 675-688

Brutsaert W (1982) Evaporation into the atmosphere: theory, history, and applications. Kluwer Academic Press, Dordrecht

Chinn TJH (1987) Accelerated ablation at a glacier ice-cliff margin, Dry Valleys, Antarctica. Arct. Alp. Res., 19(1), 71-80

Christensen JH and 16 others (2013) Climate phenomena and their relevance for future regional climate change supplementary material. In Stocker TF and 9 others eds. Climate change 2013: the physical science basis. contribution of Working Group I to the Fifth Assessment Report of the Intergovernmental Panel on Climate Change. Intergovernmental Panel on Climate Change, 62

Cuffey K and Paterson (2010) The physics of glaciers, 4th edn. Butterworth-Heinneman, Amsterdam

Dadic R, Mott R, Lehning M, Carenzo M, Anderson B and Mackintosh A (2013a) Sensitivity of turbulent fluxes to wind speed over snow surfaces in different climatic settings. Adv. Water Resour., 55, 178-189 (doi: 10.1016/j.advwatres.2012. 06.010)

Dadic R, Mullen PC, Schneebeli M, Brandt RE and Warren SG (2013b) Effects of bubbles, cracks, and volcanic tephra on the spectral albedo of bare ice near the Transantarctic Mountains: 
implications for sea-glaciers on Snowball Earth. J. Geophys. Res. Earth Surf., 118, n/a-n/a (doi: 10.1002/jgrf.20098)

Dana GL and Wharton RA, Jr (1998) Solar radiation in the McMurdo Dry Valleys, Antarctica. In Priscu JC ed. Ecosystem dynamics in a polar desert; the McMurdo Dry Valleys, Antarctica, 39-64

Dana GL, Davis RE, Fountain AG and Wharton RA, Jr (2002) Satellite-derived indices of stream discharge in Taylor Valley, Antarctica. Hydrol. Process, 16(8), 1603-1616

Doran PT and 6 others (2002a) Valley floor climate observations from the McMurdo Dry Valleys, Antarctica, 1986-2000. J. Geophys. Res. D, Atmos., 107(D24), 12-13

Doran PT and 12 others (2002b) Antarctic climate cooling and terrestrial ecosystem response. Nature, 415(6871), 517-520

Doran PT, McKay CP, Fountain AG, McKnight DA and Barrett JE (2008) Hydrologic response to extreme warm and cold summers in the McMurdo Dry Valleys, East Antarctica. Antarct. Sci., 20(5), 499-509

Dozier J and Frew J (1990) Rapid calculation of terrain parameters for radiation modeling from digital elevation data. IEEE Trans. Geosci. Remote Sens., 28(5), 963-969

Drewry DJ, Jordan SR and Jankowski E (1982) Measured properties of the Antarctic ice sheet: surface configuration, ice thickness, volume, and bedrock characteristics. Ann. Glaciol., 3, 83-91

Ebnet AF, Fountain AG, Nylen TH, McKnight DM and Jaros C (2005) A temperature-index model of streamflow at below-freezing temperatures in Taylor Valley, Antarctica. Ann. Glaciol., 40, 76-82

Eveland JW, Gooseff MN, Lampkin DJ, Barrett JE and TakacsVesbach CD (2013) Seasonal controls on snow distribution and aerial ablation at the snow-patch and landscape scales, McMurdo Dry Valleys, Antarctica. Cryosphere, 7(3), 917-931 (doi: 10.5194/tc-7-917-2013)

Flerchinger GN, Xaio W, Marks D, Sauer TJ and Yu Q (2009) Comparison of algorithms or incoming atmospheric long-wave radiation. Water Resour. Res., 45, W03423

Foreman CM, Wolf CF and Priscu JC (2004) Impact of episodic warming events on the physical, chemical and biological relationships of lakes in the McMurdo Dry Valleys, Antarctica. Aquat. Geochem., 10, 3-4

Fountain AG, Dana GL, Lewis KJ, Vaughn BH and McKnight DM (1998) Glaciers of the McMurdo dry valleys, southern Victoria Land, Antarctica. In Priscu JC ed. Ecosystem dynamics in a polar desert; the McMurdo Dry Valleys, Antarctica, $65-75$

Fountain AG, Lewis KJ and Doran PT (1999a) Spatial climatic variation and its control on glacier equilibrium line altitude in Taylor Valley, Antarctica. Global Planet. Change, 22, 1-10

Fountain AG and 12 others (1999b) Physical controls on the Taylor Valley ecosystem, Antarctica. Bioscience, 49(12), 961-971

Fountain AG, Tranter M, Nylen TH, Lewis KJ and Mueller DR (2004) Evolution of cryoconite holes and their contributions to meltwater runoff from glaciers in the McMurdo Dry Valleys, Antarctica. J. Glaciol., 50(168), 35-45

Fountain AG, Nylen TH, MacClune KL and Dana GL (2006) Glacier mass balances (1993-2001), Taylor Valley, McMurdo Dry Valleys, Antarctica. J. Glaciol., 52(178), 451-462

Fountain AG, Nylen TH, Monaghan A, Basagic J and Bromwich D (2009) Snow in the McMurdo Dry Valleys, Antarctica (doi: 10.1002/joc)

Fountain AG, Nylen TH, Monaghan A, Basagic HJ and Bromwich D (2010) Snow in the McMurdo Dry Valleys, Antarctica. Int. J. Climatol., 30(5), 633-642

Fountain AG, Levy JS, Gooseff MN and Van Horn D (2014) The McMurdo Dry Valleys: a landscape on the threshold of change. Geomorphology (doi: 10.1016/j.geomorph.2014.03. 044)

Gardner AS and Sharp MJ (2010) A review of snow and ice albedo and the development of a new physically based broadband albedo parameterization. J. Geophys. Res., 115, F01009

Gerbaux M, Genthon C, Etchevers P, Vincent C and Dedieu JP (2005) Surface mass balance of glaciers in the French Alps: distributed modeling and sensitivity to climate change. J. Glaciol., 51(175), 561-572 (doi: 10.3189/172756505781829133)

Gillies JA, Nickling WG and Tilson M (2013) Frequency, magnitude, and characteristics of aeolian sediment transport: McMurdo Dry Valleys, Antarctica. J. Geophys. Res. Earth Surf., 118, 461-479 (doi: 10.1002/jgrf.20007)

Gooseff MN, Lyons WB, McKnight DM, Vaughn BH, Fountain AG and Dowling C (2006) A stable isotopic investigation of a polar desert hydrologic system, McMurdo Dry Valleys, Antarctica. Arct. Antarct. Alp. Res., 38(1), 60-71

Grenfell TC, Light B and Sturm M (2002) Spatial distribution and radiative effects of soot in the snow and sea ice during the SHEBA experiment. J. Geophys. Res., 107(C10), 1-7 (doi: 10.1029/ 2000JC000414)

Hagedorn B, Sletten RS, Hallet B, McTigue DF and Steig EJ (2010) Ground ice recharge via brine transport in frozen soils of Victoria Valley, Antarctica: insights from modeling $\delta^{18} \mathrm{O}$ and

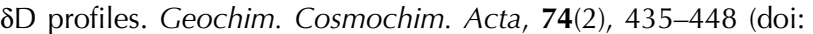
10.1016/j.gca.2009.10.021)

Hall BL, Denton GH, Fountain AG, Hendy $\mathrm{CH}$ and Henderson GM (2010) Antarctic lakes suggest millennial reorganizations of Southern Hemisphere atmospheric and oceanic circulation. Proc. Natl Acad. Sci. USA, 107(50), 21355-21359 (doi: 10.1073/pnas.1007250107)

Hock R and Holmgren B (2005) A distributed surface energybalance model for complex topography and its application to Storglaciären, Sweden. J. Glaciol., 51(172), 25-36

Hoffman MJ (2011) Spatial and temporal variability of glacier melt in the McMurdo Dry Valleys, Antarctica. Portland State University

Hoffman MJ, Fountain AG and Liston GE (2008) Surface energy balance and melt thresholds over 11 years at Taylor Glacier, Antarctica. J. Geophys. Res., 113(F4), F04014 (doi: 10.1029/ 2008JF001029)

Hoffman MJ, Fountain AG and Liston GE (2014) Near-surface internal melting: a substantial mass loss on Antarctic Dry Valley glaciers. J. Glaciol., 60(220), 361-374 (doi: 10.3189/2014JoG13J095)

Jaros CL (2003) Temperature-elevation effect on glacial meltwater generation in dry valley streams. University of Colorado

Jaros CL, McKnight DM, Gooseff MN, Fountain AG and Nylen TH (2014) Changing climatic drivers of interannual flow variation for glacial meltwater streams in Antarctica: application of a temperature index model for a twenty year record for nine streams in Taylor Valley, South Victoria Land. J. Hydrol., In review

Jepsen SM, Adams EE and Priscu JC (2010) Sediment melt-migration dynamics in perennial Antarctic lake ice. Arct. Antarct. Alp. Res., 42(1), 57-66 (doi: 10.1657/1938-4246-42.1.57)

Johnston RR (2004) Channel morphology and surface energy balance on Taylor Glacier, Taylor Valley, Antarctica. Portland State University, Portland, OR

Johnston RR, Fountain AG and Nylen TH (2005) The origin of channels on lower Taylor Glacier, McMurdo Dry Valleys, Antarctica, and their implication for water runoff. Ann. Glaciol., 40, 1-7

Jonsell U, Hock R and Holmgren B (2003) Spatial and temporal variations in albedo on Storglaciären, Sweden. J. Glaciol., 49(164), 59-68 (doi: 10.3189/172756503781830980)

Jonsell UY, Navarro FJ, Bañón M, Lapazaran JJ and Otero J (2012) Sensitivity of a distributed temperature-radiation index melt model based on AWS observations and surface energy balance fluxes, Hurd Peninsula glaciers, Livingston Island, Antarctica. Cryosphere, 6(3), 539-552 (doi: 10.5194/tc-6-539-2012)

Keys JR (1980) Air temperature, wind, precipitation and atmospheric humidity in the McMurdo region, Victoria. Antarctic Data Series, Victoria University, Wellington

Klok EJL and Oerlemans J (2002) Model study of the spatial distribution of the energy and mass balance of Morteratschgletscher, Switzerland. J. Glaciol., 48(163), 505-518

Klok EJL, Greuell W and Oerlemans J (2003) Temporal and spatial variation of the surface albedo of Morteratschgletscher, Switzerland, as derived from 12 Landsat images. J. Glaciol., 49, 491-502 
König-Langlo G and Augstein E (1994) Parameterization of the downward longwave radiation at the Earth's surface in polar regions. Meteorol. Z., 3, 343-347

Konzelmann T, van de Wal RSW, Greuell W, Bintanja R, Henneken EAC and Abe-Ouchi A (1994) Parameterization of global and longwave incoming radiation for the Greenland ice sheet. Global Planet. Change, 9(1-2), 143-164

Korona J, Berthier E, Bernard M, Rémy F and Thouvenot E (2009) SPIRIT. SPOT 5 stereoscopic survey of Polar Ice: Reference Images and Topographies during the fourth International Polar Year (2007-2009). ISPRS J. Photogramm. Remote Sens., 64, 204-212

Levy J (2012) How big are the McMurdo Dry Valleys? Estimating icefree area using Landsat image data. Antarct. Sci., 25(1), 119-120

Levy JS and 6 others (2013) Accelerated thermokarst formation in the McMurdo Dry Valleys, Antarctica. Sci. Rep., 3, 2269 (doi: 10.1038/srep02269)

Lewis KJ (2001) Solar-forced roughening of Antarctic glaciers and the Martian icecaps; how surficial debris and roughness affect glacial melting in Taylor Valley, Antarctica and how this can be applied to the Martian icecaps. University of Colorado, Boulder, CO

Lewis KJ, Fountain AG and Dana GL (1998) Surface energy balance and meltwater production for a Dry Valley glacier, Taylor Valley, Antarctica. Ann. Glaciol., 27, 603-609

Lewis KJ, Fountain AG and Dana GL (1999) How important is terminus cliff melt? A study of the Canada Glacier terminus, Taylor Valley, Antarctica. Global Planet. Change, 22, 1-4

Liston GE and Elder K (2006) A meteorological distribution system for high-resolution terrestrial modeling (MicroMet). J. Hydrometeorol., 7, 217-234

Liston GE, Winther J-G, Bruland O, Elvehoy H and Sand K (1999) Below-surface ice melt on the coastal Antarctic ice sheet. J. Glaciol., 45(150), 273-285

Liu BYH and Jordan RC (1960) The interrelationship and characteristic distribution of direct, diffuse and total solar radiation. Sol. Energy, 4(3), 1-19

MacClune KL, Fountain AG, Kargel JS and MacAyeal DR (2003) Glaciers of the McMurdo Dry Valleys; terrestrial analog for Martian polar sublimation. J. Geophys. Res. E, Planets, 108(E4), 5031 (doi: 10.1029/2002JE001878)

MacDonell SA, Fitzsimons SJ and Mölg T (2012) Seasonal sediment fluxes forcing supraglacial melting on the Wright Lower Glacier, McMurdo Dry Valleys, Antarctica. Hydrol. Process, (doi: 10.1002/hyp.9444)

McKnight DM, Niyogi DK, Alger AS, Bomblies A, Conovitz PA and Tate CM (1999) Dry Valley streams in Antarctica: ecosystems waiting for water. Bioscience, 49(12), 985-995

Mölg T, Cullen NJ, Hardy DR, Kaser G and Klok L (2008) Mass balance of a slope glacier on Kilimanjaro and its sensitivity to climate. Int. J. Climatol., 881-892 (doi: 10.1002/joc)

Nielsen UN and 6 others (2012) The ecology of pulse events: insights from an extreme climatic event in a polar desert ecosystem. Ecosphere, 3(2), 17
Nylen TH, Fountain AG and Doran PT (2004) Climatology of katabatic winds in the McMurdo Dry Valleys, southern Victoria Land, Antarctica. J. Geophys. Res., 109(D3), D03114 (doi: 10.1029/2003JD003937)

Oerlemans J and Fortuin JP (1992) Sensitivity of glaciers and small ice caps to greenhouse warming. Science, 258(5079), 115-117 (doi: 10.1126/science.258.5079.115)

Oerlemans J and 10 others (1998) Modelling the response of glaciers to climate warming. Clim. Dyn., 14(4), 267-274 (doi: 10.1007/ s003820050222)

Pirazzini R, Nardino M, Orsini A, Calzolari F, Georgiadis T and Levizzani V (2001) Parameterization of the downward longwave radiation from clear and cloudy skies at Ny Ålesund (Svalbard). In Smith YM, WL and T ed. IRS 2000: current problems in atmospheric radiation. A. Deepack Publishing, Hampton, VA, 559-562

Šabacká M and 6 others (2012) Aeolian flux of biotic and abiotic material in Taylor Valley, Antarctica. Geomorphology, 155-156, 102-111 (doi: 10.1016/j.geomorph.2011.12.009)

Skartveit A and Olseth JA (1987) A model for the diffuse fraction of hourly global radiation. Sol. Energy, 38(4), 271-274

Skartveit A, Olseth JA and Tuft ME (1998) An hourly diffuse fraction model with correction for variability and surface albedo. Sol. Energy, 63(3), 173-183

Smeets P and van den Broeke M (2008) Temporal and spatial variations of the aerodynamic roughness length in the ablation zone of the Greenland ice sheet. Boundary-Layer Meteorol., 128, 315-338

Speirs JC, Steinhoff DF, McGowan HA, Bromwich DH and Monaghan AJ (2010) Foehn winds in the McMurdo Dry Valleys, Antarctica: the origin of extreme warming events. J. Clim., 23, 3577-3598

Speirs JC, McGowan HA, Steinhoff DF and Bromwich DH (2013) Regional climate variability driven by Foehn winds in the McMurdo Dry Valleys, Antarctica. Int. J. Climatol., 33(4), 945958 (doi: 10.1002/joc.3481)

Steig EJ and 7 others (2000) Wisconsinan and Holocene climate history from an ice core at Taylor Dome, Western Ross Embayment, Antarctica. Geogr. Ann. Ser. A, Phys. Geogr., 82A, 213-235

Taylor KE (2001) Summarizing multiple aspects of model performance in a single diagram. J. Geophys. Res., 106, 7183-7192

US Geological Survey (2012) High Resolution Lidar Digital Elevation Models and Low Resolution Shaded Relief Maps of Antarctica from USGS: McMurdo Dry Valleys Lidar Dataset

Warren SG (1984) Impurities in snow: effects on albedo and snowmelt. Ann. Glaciol., 5, 177-179

Wiscombe WJ and Warren SG (1980a) A model for the spectral albedo of snow. II. Snow containing atmospheric aerosols. J. Atmos. Sci., 37, 2734-2745

Wiscombe WJ and Warren SG (1980b) A model for the spectral albedo of snow. I. Pure snow. J. Atmos. Sci., 37, 2712-2733 